\title{
Article
}

\section{Serious mortality: the date of the Fussell's Lodge long barrow}

Wysocki, Michael Peter, Bayliss, A and Whittle, A

Available at http://clok.uclan.ac.uk/324/

Wysocki, Michael Peter, Bayliss, A and Whittle, A (2007) Serious mortality: the date of the Fussell's Lodge long barrow. Cambridge Archaeological Journal, 17 (S1). pp. 65-84. ISSN 0959-7743

It is advisable to refer to the publisher's version if you intend to cite from the work. http://dx.doi.org/10.1017/S0959774307000170

For more information about UCLan's research in this area go to http://www.uclan.ac.uk/researchgroups/ and search for < name of research Group>.

For information about Research generally at UCLan please go to http://www.uclan.ac.uk/research/

All outputs in CLoK are protected by Intellectual Property Rights law, including Copyright law. Copyright, IPR and Moral Rights for the works on this site are retained by the individual authors and/or other copyright owners. Terms and conditions for use of this material are defined in the policies page.

\section{CLoK}

Central Lancashire online Knowledge www.clok.uclan.ac.uk

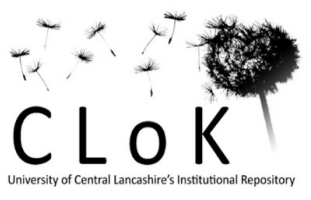




\title{
Serious Mortality: the Date of the Fussell's Lodge Long Barrow
}

\author{
Michael Wysocki, Alex Bayliss \& Alasdair Whittle
}

\begin{abstract}
Twenty-seven radiocarbon results are now available from the Fussell's Lodge long barrow, and are presented within an interpretive Bayesian statistical framework. Three alternative archaeological interpretations of the sequence are given, each with a separate Bayesian model. It is hard to decide between these, though we prefer the third. In the first (following the excavator), the construction is a unitary one, and the human remains included are by definition already old. In the second, the primary mortuary structure is seen as having two phases, and is set within a timber enclosure; these are later closed by the construction of a long barrow. In that model of the sequence, deposition began in the thirty-eighth century cal. $B C$ and the mortuary structure was extended probably in the 3660s-3650s cal. BC; the long barrow was probably built in the 3630s-3620s cal. BC; ancestral remains are not in question; and the use of the primary structure may have lasted for a century or so. In the third, preferred model, a variant of the second, we envisage the inclusion of some ancestral remains in the primary mortuary structure alongside fresh remains. This provides different estimates of the date of initial construction (probably in the last quarter of the thirty-eighth century cal. $в$ с or the first half of the thirty-seventh century cal. $\mathrm{BC}$ ) and the duration of primary use, but agrees in setting the date of the long barrow probably in the 3630s-3620s cal. $B C$. These results are discussed in relation to the development and meanings of long barrows at both national and local scales.
\end{abstract}

The Fussell's Lodge long barrow is one of the most cited monuments of the early part of the Neolithic in southern Britain. Both its pre-barrow structure and contents and the overlying long mound have been the subject of considerable comment and discussion (Ashbee 1966; 1970; Shanks \& Tilley 1982; Thomas 1991; Kinnes 1992). It lies, rather isolated, to the east of the rivers Avon and Bourne in south Wiltshire, with only one neighbour about $3 \mathrm{~km}$ to the northeast, and is not therefore part of the denser concentrations to the west and north of Stonehenge (Ashbee 1970, fig. 6; no. 5 in the Salisbury Plain East distribution). It was built on relatively low ground on the Upper Chalk, on the side of a broad dry valley, which runs down to the confluence of the Bourne, Avon and Nadder valleys to the southwest (SU 1920 3246; 5105'28" N; $\left.01^{\circ} 43^{\prime} 38^{\prime \prime} \mathrm{W}\right)$.
Discovered by aerial photography in the 1920s, the barrow was excavated by Paul Ashbee in 1957 'following upon, and in the face of, extensive plough damage' (Ashbee 1966, 2). The trapezoidal or wedgeshaped barrow was contained within a continuous timber revetment, and flanked by a substantial ditch on each long side (Fig. 1; Ashbee 1966, fig. 2). Under the east and broader end of the barrow there was a structure or setting defined by three well-spaced pits $(\mathrm{A}-\mathrm{C})$, the easternmost (Pit C) at the very end of the barrow cutting the bedding trench of the timber revetment. The three pits defined a linear zone some $7 \mathrm{~m}$ long, containing five groups of human remains, and covered by what the excavator described as a 'flint cairn', which was built on the old ground surface. That lay directly over the human remains, and was in turn covered by the material of the barrow; ox foot 


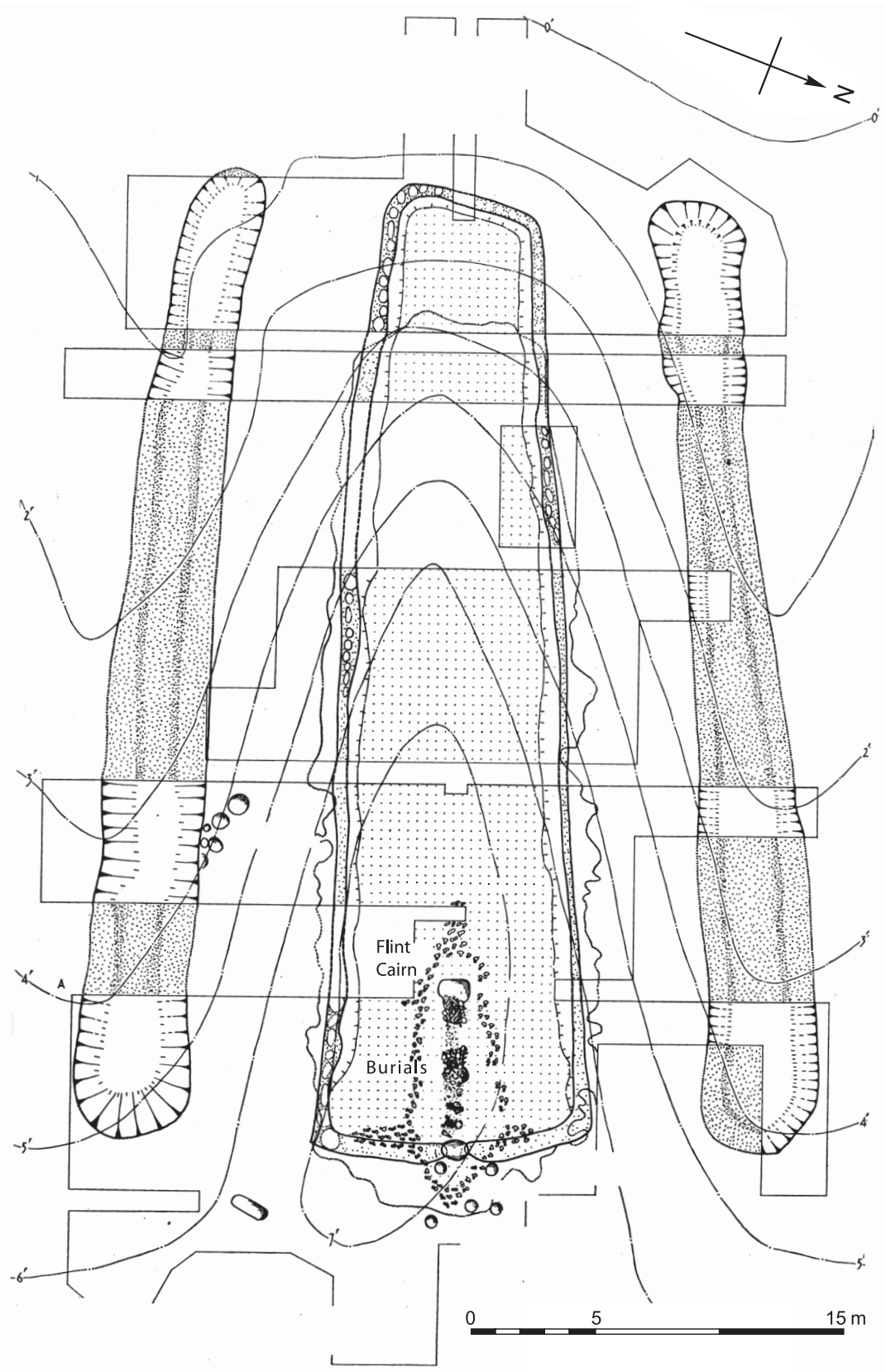

Figure 1. The Fussell's Lodge long barrow.
Bone Group A and with Bone Group D; further sherds of early style were found in the old land surface and in the flint cairn (Ashbee 1966, 17). A single radiocarbon date on a sample of oak charcoal from the pre-barrow structure (the 'mortuary house' in Ashbee's terms: 1966, 27) gave a determination suggesting a date early in the Neolithic sequence (Ashbee 1966, 27-8); Ashbee noted the possibility of an old wood effect on this date but had identified the sample as a branch or small root (Ashbee 1966, 28).

Ashbee discussed whether the timber revetment or enclosure had had 'a use-life distinct from that of the barrow as an entity', with the space of the timber enclosure used for 'provisional burial' $(1966,30)$. His preferred view, however, was of a single act of interment, of bones brought from elsewhere, since there were no human bones found scattered on the old land surface under the infilled revetment. Human remains were supposed to have been stacked in the roofed mortuary house 'either during or after its construction' (Ashbee 1966, 32). The flanking ditches might have followed or been laid out at the same time as the revetment (Ashbee 1966, 28), and it is implied (without being fully explicit, since the rest of the relevant discussion is given over to structural considerations, except for a brief later reference to 'the apparent unity of the burial complex': Ashbee 1966, 37) that the whole monument was essentially a unitary construction.

There was no clear evidence in section that the three pits of the mortuary structure had held posts,

bones on its upper surface may have come from a hide draped over the cairn. The bone groups lay between Pits A and C, just overlapping the edge of the former, but lay over the fill of Pit B. These are described in more detail below. Directly outside the east end of the barrow was a small setting of postholes, called a 'porch' by the excavator.

Bowl pottery, some decorated and with resemblances to both the Windmill Hill and Mildenhall styles, was found with the human remains, under human bone in their upper fills as showing that there had been a process of post replacement (Ashbee 1966, 2,8 ), and envisaged some kind of three-post tent-like structure overlying the human remains, further covered by the flint cairn (Ashbee 1966, 37-42; 1970, 51, and classically, fig. 34; cf. Atkinson 1965; Piggott 1966, 385). One must note that other interpretations have also been suggested, in which tent-like structures as such play no part (Morgan \& Ashbee 1958, 109-10; but the excavator interpreted the inclusion of some 
Kinnes 1975; 1992; Whittle 1991; Thomas 1991; 1999). It is important to note that the excavator explicitly stated (Ashbee 1966, 4, 8) that Pit C 'slighted the entrance to the enclosure' and 'had been dug across what had presumably been an entrance to the trapezoid enclosure between the ends of the bedding trench' (though Thomas (1999, 131, fig. 6.5) has inferred the opposite sequence, giving a constructional priority to the 'mortuary structure' over the timber enclosure). The excavator assumed that all three pits, or in his view post-pits, belonged together.

For our purposes, further key insights about the character of the pre-barrow arrangements and the sequence have been offered by Ian Kinnes (1975; 1992; see also Simpson 1968). The idea of a single, recurrent, tent-like mortuary structure was replaced by him with a range of mainly linear arrangements, often embanked, but variously defined by pits, planks or posts (Kinnes 1992, 81-8). In the specific case of Fussell's Lodge, Kinnes suggested, following the excavator's observation of the relationship between Pit $\mathrm{C}$ and the bedding trench of the timber enclosure, the separation of Pit $C$ from an initial linear zone defined by Pits $A$ and B, and Bone Groups A1, A2, B, C and D (Kinnes $1992,26,86)$. In this view, though the question is left a little open, Pit $C$ becomes part of a blocking episode, accompanied by the deposition of a few further human remains in the form of Bone Group E (Kinnes 1992, 26, 86, fig. 1D.6; cf. Ashbee 1966, 12). From this follows the further possibility that the mortuary deposit as a whole 'could represent successive placing from rear to front, or a controlled apportionment of space' (Kinnes 1992, 104). We can add a variant to the model of successive placing, by suggesting a primary phase defined by Pits A and B (with or without posts, and discussed further below) and Bone Groups A1, A2 and $\mathrm{B}$, followed by a subsequent extension incorporating Bone Groups C and D.

\section{The mortuary deposits (Fig. 2)}

The human skeletal archive from Fussell's Lodge was extensively examined during the course of the wider osteological study mentioned in the previous paper in this volume on West Kennet (Wysocki \& Whittle in prep.). Unfortunately the curated material has suffered some deprivation in the years since it was excavated (which will be detailed elsewhere), so it has not been possible to confirm or review all aspects of the original bone report written by Brothwell \& Blake (1966). As might be expected, advances in methods, techniques and knowledge in the forty or so years since the publication of Fussell's Lodge mean that some revision of Brothwell \& Blake's (1966) findings is necessary, but these are largely demographic or osteological in nature and do not impact significantly on the sampling strategy for the dating project.

Abutting the innermost pit, Pit A, were Bone Groups A1 and A2: adjacent assemblages of mainly adult bones, with disarticulated long bones and postcranial fragments bundled or stacked more or less along the long axis of the structure and with skulls and fragmentary cranial remains concentrated along the outer sides of the stacks.

Going towards the east end of the barrow, there was then a linear and relatively sparse scatter of children's cranial and postcranial fragments, and then Bone Group B, another bundled stack, some of which lay right across Pit $\mathrm{B}$. Here the arrangement was less ordered than in Groups A1 and A2, with long bones lying transverse or diagonal to the axis of the monument. The human bone from the upper part of the fill of Pit B was cremated or burnt. There is no evidence of any burning on any of the other human material from the mortuary area.

Bone Groups C and D lay, in linear sequence, between Pit B and Pit C at the 'entrance'. When first exposed, these appeared to the excavators each to represent single contracted inhumations but each was subsequently shown to contain the partial disarticulated remains of two individuals (thus drawn from four individuals altogether). An ox skull was found directly in front of Pit $C$, and formed the outermost part of the deposit as a whole. A group of ox foot bones, representing a left forefoot and right and left hind feet (Grigson 1966), were recovered from the top of the flint cairn covering the human remains, placed more or less in the middle of the structure and along its long axis. Finally, numerous small fragments and scraps of human and animal bone were recovered from amongst the flint nodules of the 'cairn'. These were designated Group E (Ashbee 1966, 12).

Fussell's Lodge remains one of the few excavated earthen long barrows to yield a substantial quantity of human remains. Ashbee's (1966) report estimated a maximum of 53 to 57 individuals to be represented, but, even taking into account material that has been lost or irretrievably damaged in the years since publication, this figure is very much an over-estimate. Following current standard analytical procedure for estimating Minimum Number of Individuals (MNI) presented by White $(2000,291)$ we estimate an MNI of 34 individuals: 26 adults and 8 children or adolescents (cf. Mays 1998, 29).

Ashbee (1966) argued that the bones were brought from elsewhere for secondary burial in the 


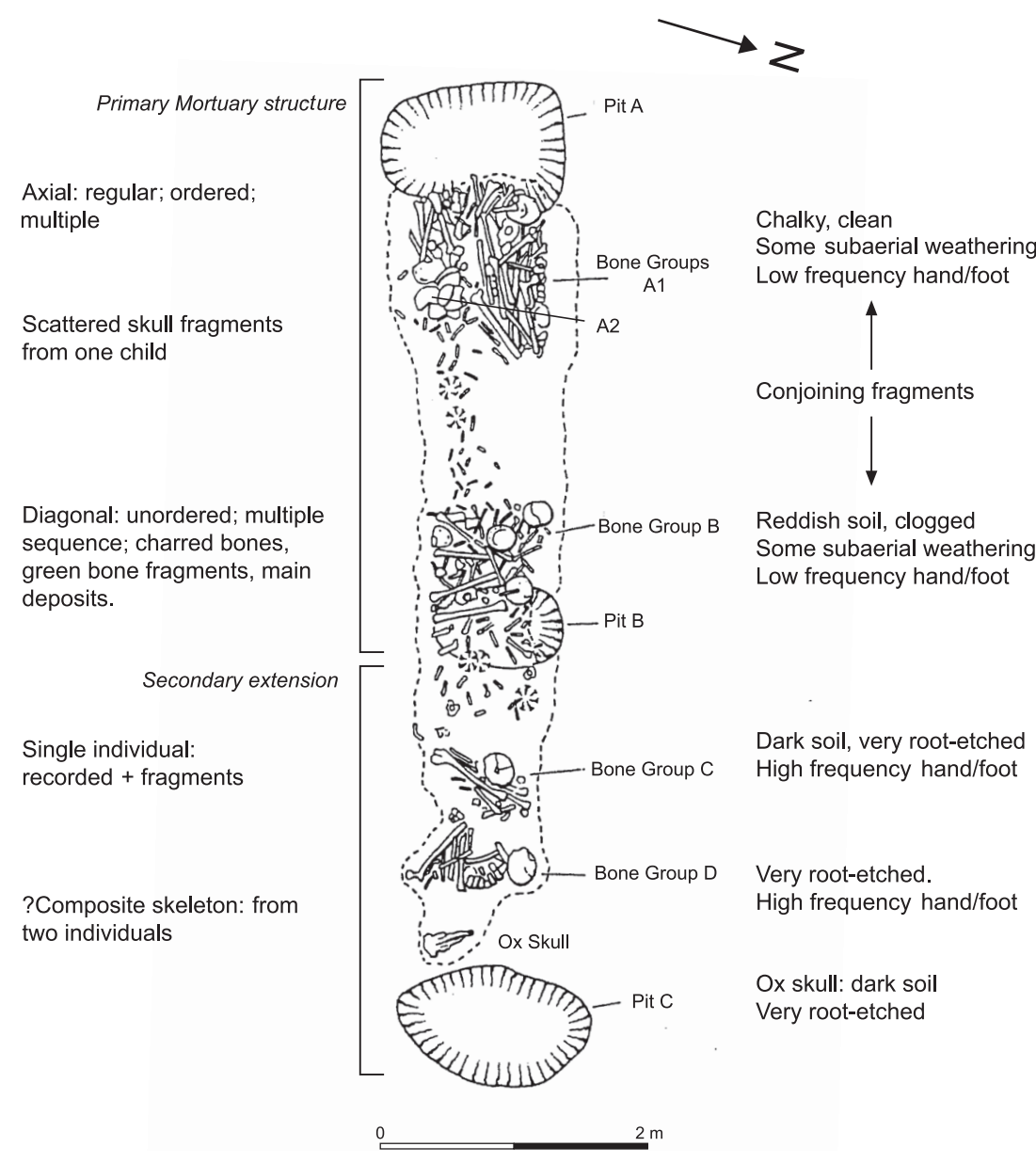

Figure 2. The mortuary deposits.

monument. This conclusion was based on a number of observations, first that already disarticulated skeletal remains were reordered and stacked to form the groups. Secondly, many of the bones were much 'weathered' (Ashbee 1966, passim). Thirdly, it was noted that, in the case of Group B, the interstices between the bones were filled with soil, and that many of the small fragments of bone found at the base of Groups A1/A2 and B were also mixed and soiled with chalky grey brown earth, in contrast to the black old ground surface on which they lay. This suggested to Ashbee the possibility that some of the remains had been exhumed before reburial (1966, 8, 37-8). Furthermore, Ashbee claimed $(1966,9)$ that although some of the many broken shafts comprising the Bone Groups were clearly the result of static loading forces from the overlying cairn/mound, others lay at 'discrete angles and with pieces considerably removed from one another, and with parts missing', and that this indicated that the bones were already broken when brought to the barrow for interment. A broader supporting argument was the lack of any bones scattered outside of the relatively confined space of the mortuary house area, on the old land surface defined by the timber enclosure, which it was felt would have accompanied or been the result of 'provisional' burial (Ashbee 1966, 9, 30). Finally, the underrepresentation of hand and foot bones was taken to indicate transport of defleshed, disarticulated material to the monument from elsewhere, with consequent loss of small, insignificant, phalanges and wrist and ankle bones (Brothwell \& Blake 1966, 62; Mays 1998, 29-31).

Following re-examination of the material we can add the following points. Almost none of the material displays evidence of subaerial weathering (see Wysocki 1998) with $92.7 \%$ at weathering stage 0 , the rest at weathering stage 1 . The bones are, however, extensively root-etched, though this need not necessarily imply that the bones had been buried elsewhere before placement in the barrow, particularly in view of the extensive loss of mound material. With the exception of a few rodent-modified specimens, there is no evidence of animal scavenging on any of the bones. Neither is there any evidence of cut marks or incisions to suggest dismemberment, as has been found at other Neolithic barrows (Wysocki \& Whittle 2000, 595; Smith \& Brickley 2004).

Remnants of adhering soil and patination of the bones show distinct differences between groups (Group A1/A2 white chalky soil, Group B red-brown soil and patination, Groups C, D and Ox skull greybrown soil and patination). This could suggest that the bone groups were originally exhumed from different locations and brought to the barrow, but could also reflect localized differences in the soil/barrow matrix of the barrow. It is not possible to check this now, though there is some suggestion that this may have been the case with Group B (Ashbee 1966, 10).

Severe under-representation of hand and foot bones is evident in Groups A1/A2 and B with survival of only $5.9 \%$ of the expected number for an MNI of 22 adults. This figure can be compared to frequencies of $18.7 \%$ for West Kennet and $30.3 \%$ for Wayland's Smithy (Wysocki \& Whittle in prep.), which were both 
excavated at a similar period to Fussell's Lodge, using similar techniques and procedures, and which both represent broadly similar burial environments. One should also note that the situation in Groups A1/A2 and B can be contrasted to that in Groups C and D where hand and foot bones total $21.5 \%$ of the expected number for an MNI of four adults. On the other hand, some under-representation of such elements is a common feature of exhumed skeletal assemblages from all periods and a variety of different contexts (Waldron 1987; Mays 1998; Cox \& Bell 1999; Ubelaker 2002).

Broken and incomplete limb shafts from the bone groups consistently display fracture characteristics associated with dry bone breakage (see Wysocki 1998), indicating that this material was already relatively old when broken, lacking the intrinsic bone moisture and resilience of fresh bone. However, from the base of Group B a sub-assemblage of over 300 small fragments and splinters of upper and lower limb bones (some $30 \%$ of the basal material) exhibits fracture morphology suggesting the breakage of relatively 'fresh' green bone (v-shaped/spiral fractures), in contrast to the larger specimens that constitute Group B proper. At the time of sample selection and modelling for this dating project, it was thought possible that this material could be residual from an earlier phase of mortuary activity than that represented by Group B itself. However, it could also represent the admixture, in Group B, of skeletal material from relatively recently deceased individuals as well as older ancestral remains.

Finally (contra Brothwell \& Blake 1966, 48), a distal portion of a right adult tibia from Group B has been found to conjoin with a right tibia shaft from Group A1. The fracture characteristics (transverse, right angled) are consistent with dry bone, post mortem breakage patterns.

On the whole, our observations tend to support the position taken by Ashbee (1966) that some of the human material may have been brought to Fussell's Lodge in a disarticulated state. However, the evidence, such as it is, is far from unequivocal, and it remains possible that fleshed corpses could have been left to decompose and disarticulate in situ at Fussell's Lodge. Whatever the case, it is clear that:

1. already disarticulated material was stacked and grouped in the mortuary area;

2. some of the material was already in a broken or brittle, dry bone, condition at the time of stacking;

3. at least some bones in the different groups were from the same individuals or sources.

The timescales involved in such transformation of the recently deceased to dry disarticulated skeletal states are subject to a multitude of variables. Under favourable conditions one might expect complete skeletonization of buried remains to take approximately three years to five years, with a much shorter period for unburied remains (Bass 1997; Rodriguez 1997; Simmons 2002). The transition from green bone to dry bone may take considerably longer, possibly decades, depending on conditions. We can suggest that a minimum period of between five to ten years, and very possibly at least two or three times that, may have passed between the deaths of the individuals represented at Fussell's Lodge and the final arrangement of their mortal remains. It should be noted that chronological resolution at this scale is beyond that provided by the scientific dating techniques normally available to archaeologists working in Britain.

\section{Animal bone samples}

Grigson (1966) reported that five red deer antlers were recovered from the primary chalk rubble fill of the ditch (layer 10 in the section drawing: Ashbee 1966, pl. XIV), and states that 'the antler found in the lowest layer [10] might have been left there during the construction of the barrow' $(1966,66)$, but the precise location of the antlers (within, or at the bottom of, the primary fill) remains unclear. One antler $(\Delta 15 \mathrm{CS} / \mathrm{FSA} 1)$ is labelled as coming from layer 11, and the depth co-ordinate ( $\left(9^{\prime} 8^{\prime \prime}\right)$ is the greatest of any of the antler specimens from that ditch segment (CS). Layer 11 is not shown in the section drawings, which suggests that this specimen was at the very base of the primary fill (layer 10). Other antlers from the same ditch segment are labelled as coming from layers 10 or 9 and were found at slightly higher depths in the primary fill (9'4" and 9'3" respectively). 15CS/FSA1 was, therefore, selected as the best candidate for an antler from the ditch bottom.

\section{Ox foot bones from the top of the flint cairn}

The ox foot bones (FSA3a \& b), perhaps from a hide (see discussion below, and note 3), must give a terminus post quem for the construction of the mound. It should be noted, however, that the foot bones were not found in complete articulation, but as a 'neat pile of articulated foot bones ... lying on top of the flint stack ... and [that] a few small foot bones ... were scattered in the mortuary house cover surface to a depth of about two feet' (Grigson 1966, 65). Although not mentioned in the original report, one of the medial phalanges from the right hind foot shows clear evidence of having been burnt. The phalange is charred black and is heat-cracked all over its proximal articulating surface. The rest of this bone is a grey/buff colour, consistent 
with bone that has been exposed to fire or heat. The proximal phalange, with which it articulates, is perfectly ordinary in appearance and shows no evidence of having been exposed to heat, as is also the case with all the other ox foot bones. The charred specimen must, therefore, have been disarticulated and detached from the rest of the foot when burnt. Two of the associated metapodials display split lines consistent with stage 1 subaerial weathering changes. This indicates that the burning episode took place after a time, subsequent to the placing of the articulated ox foot bones, of sufficient duration for the foot bones to begin falling apart. Again, depending on conditions, this could be measured anywhere between three to five years to decades.

Articulated ox bones above the primary silts (FSA5 $a \mathcal{E} b$ ) Lying just above the primary fill of the south ditch, in the top of or just above layer 9, was the almost complete vertebral column of an ox, together with its ribs, mandible and shaft of left tibia. The vertebrae and ribs gave the appearance of being articulated, but a few vertebrae were missing, the axis was lying back to front, the fourth dorsal vertebra was lying in front of the axis and two other dorsal vertebrae were tipped forward. The ribs were scattered all around the column. Grigson $(1966,64-5)$ thought it unlikely that disarticulated vertebrae were laid out deliberately to give the appearance of articulation, and argued that the assemblage represented the original deposition of an articulated vertebral column with ribs, which was later disturbed. Although not noted at the time, one of the vertebrae displays two puncture marks with patinated fracture surfaces. Animal scavenging is the most likely agent of the punctures and thus disturbance of the deposit.

\section{Objectives of this study}

As with the other monuments reported in this series of papers, further dating of the Fussell's Lodge long barrow was undertaken principally because of the methodological advances in radiocarbon dating and the interpretation of radiocarbon dates which have been made in the last decade or so (Bayliss et al. this issue). These developments provide the potential to produce much more precise dating for such monuments (Bayliss \& Bronk Ramsey 2004; Bayliss et al. 1997). The monument also offered the opportunity for comparison of the dating of an earthen long barrow with that of the other cairns reported in this series of papers.

Specifically, the new dating programme was designed to address the following objectives:
- to date the construction of the primary structures (timber revetment and mortuary structure) under the long barrow;

- to determine the dates of the mortuary deposits and their chronological span;

- to investigate whether there are any differences in date between the separate bone groups of the mortuary deposits;

- to determine whether the 'green bone' in Group $\mathrm{B}$, which exhibits a fracture morphology of fresh breaks, is earlier in date than the overlying 'dry bone' material, which exhibits a fracture morphology consistent with post mortem breakage;

- to determine if the weathered ox skull incorporated at the proximal end of the mortuary deposits was older than the human remains;

- to establish the date of the construction of the long barrow;

- to establish the relative position of Fussell's Lodge in the typological sequence of long barrows and long cairns (Corcoran 1969; Ashbee 1970; Darvill 1982; Saville 1990; Thomas 1991).

Fussell's Lodge was also part of a wider project on human remains and mortuary processes and results of the detailed osteological research there will be provided elsewhere (Wysocki \& Whittle in prep.).

\section{Sampling}

A simulation of the likely chronology of the monument was constructed to assess the number of samples which would be required to answer these questions to a resolution which would be archaeologically useful (Fig. 3). This was done using the R_Simulate function of OxCal (version 3.5) with the calibration curve of Stuiver et al. (1998), archaeological estimates for the likely date of the material (see BM-134: Table 1), and estimated error terms for the radiocarbon measurements based on the available samples.

Certain types of sample were targeted for dating. In particular, samples which could not be from a secondary context were preferred. The categories of material selected for dating were:

- articulated animal bone groups which could not have been deposited more than a few years or so after the death of the animal concerned, or they would have been dispersed (cf. Mant 1987, 71);

- pieces of antler, interpreted as derived from fresh tools used in construction;

- disarticulated human remains from individuals who are identifiably distinct from one another on the basis of osteological duplications.

In addition, dating was sought for the weathered ox 
skull within the mortuary deposits (noted above).

It is important to ensure that it is known whether each dated sample is from a separate individual. This allows measurements on the same body to be combined before calibration, so that all dates included in the models are statistically independent (Bronk Ramsey 2001, 357). In addition, sampling locations on individual specimens were chosen to avoid any areas showing previous use of consolidant or adhesives.

The first series of samples submitted from Fussell's Lodge was selected to clarify the sequence of different elements of the monument. Unfortunately the antler from the timber revetment (Grigson 1966, 63) could not be located in the archive and so the construction of the timber revetment remains undated by radiocarbon measurement. Once these results were received, and a preliminary model constructed, further samples were selected to refine the absolute dating of the monument and to replicate some specimens which had provided surprisingly early results. Further samples also included 'green bone', which exhibits a fracture morphology of fresh breaks, to determine whether it was of a different date to the rest of the human bone in the mortuary deposits.

Unfortunately, shortly after the second series of measurements had been completed, a technical problem was identified with the bone preparation method used in the Oxford Laboratory (Bronk Ramsey et al. 2004a; Bayliss et al. this issue). The resolution of this problem necessitated two further series of replicate samples. Of the 22 samples originally dated, sufficient gelatin remained in archive for re-purification and re-dating of nine samples. Five of the original 22 samples were re-sampled and successfully dated. Unfortunately, insufficient gelatin remained in archive for re-dating of the other eight samples and these could not be re-sampled as the specimens in question were either too small or too fragmentary. Alternative specimens were identified and dated for five of these samples. A second antler

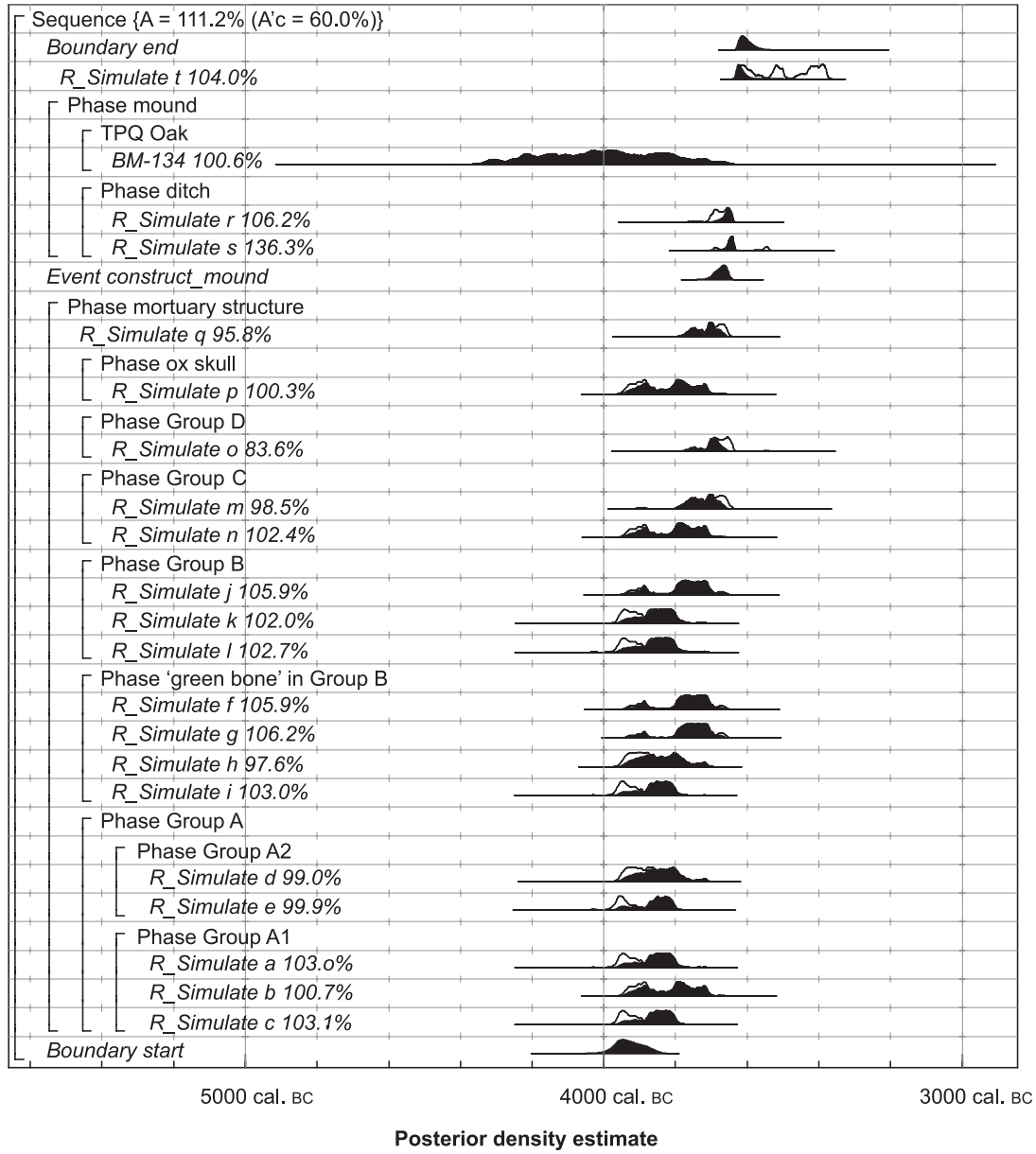

Figure 3. Probability distributions of simulated dates from Fussell's Lodge. Each distribution represents the relative probability that an event occurs at a particular time. For each radiocarbon date, two distributions have been plotted: one in outline which is the result of simple radiocarbon calibration, and a solid one based on the chronological model used; the 'event' associated with, for example, $\mathrm{k}$, is the growth of the person whose bones were dated. The other distributions correspond to aspects of the model. For example, the distribution 'start' is the posterior density estimate for the first burial activity on the site. The large square brackets down the left-hand side and the OxCal keywords define the overall model exactly.

tine from the basal fill of the southeast flanking ditch was too small for further sampling, which was particularly unfortunate as samples functionally related to the construction of the barrow itself are limited. The two samples of 'green bone' which failed to yield reliable dates were not replicated.

\section{Results}

Twenty-seven radiocarbon results are now available from Fussell's Lodge (Table 1). They come from 17 different human skeletons, three cattle, one red deer 
Michael Wysocki et al.

Table 1. Radiocarbon measurements from Fussell's Lodge long barrow. Results denoted by * have been undertaken on re-purified gelatin (see Bayliss et al. this issue).

\begin{tabular}{|c|c|c|c|c|c|c|c|c|}
\hline $\begin{array}{l}\text { Laboratory } \\
\text { no. }\end{array}$ & Sample no. and material & $\begin{array}{c}\text { Radiocarbon } \\
\text { age (вР) }\end{array}$ & \begin{tabular}{|l|}
$\delta^{13} C$ \\
$(\% o)$
\end{tabular} & $\begin{array}{l}\delta^{15} N \\
(\%)\end{array}$ & $\begin{array}{c}\mathrm{C}: \mathrm{N} \\
\text { ratio }\end{array}$ & $\begin{array}{l}\text { Weighted } \\
\text { mean (вр) }\end{array}$ & $\begin{array}{l}\text { Calibrated date } \\
\text { range }(95 \% \\
\text { confidence) }\end{array}$ & $\begin{array}{l}\text { Posterior density } \\
\text { estimate (95\% } \\
\text { probability unless } \\
\text { otherwise stated) }\end{array}$ \\
\hline BM-134 & $\begin{array}{l}\text { A piece of oak, apparently } \\
\text { carbonized by fire, found with } \\
\text { yellowed and reduced chalk } \\
\text { in the mortuary structure } \\
\text { collapse at its proximal end, } \\
\text { immediately within the } \\
\text { enclosure entrance }\end{array}$ & $5180 \pm 150$ & & & & & $4350-3690$ cal. вс & 4330-3700 cal. вС \\
\hline OxA-13205* & $\begin{array}{l}\text { FSA 1, red deer antler tip from } \\
\text { the bottom of the flanking } \\
\text { quarry ditch of the long barrow } \\
\text { (layer 11) }\end{array}$ & $4851 \pm 37$ & -23.1 & & & \multirow[t]{3}{*}{$\begin{array}{l}4866 \pm 26 \\
T^{\prime}=0.3 \\
T^{\prime}(5 \%)= \\
6.0 ; v=2\end{array}$} & \multirow[t]{3}{*}{ 3780-3540 cal. вс } & \multirow[t]{3}{*}{$3650-3630 \mathrm{cal}$. вс } \\
\hline GrA-28199 & replicate of OxA-13205 & $4880 \pm 50$ & -23.4 & & & & & \\
\hline GrA-28218 & auto-duplicate of GrA-28199 & $4880 \pm 50$ & -23.4 & & & & & \\
\hline OxA-13173* & $\begin{array}{l}\text { FSA 3, ox metapodial from the } \\
\text { surface of the flint cairn. Part of } \\
\text { a deposit of bones which form } \\
\text { three articulating ox feet (one } \\
\text { front, two hind), plus caudal } \\
\text { vertebrae }\end{array}$ & $4728 \pm 49$ & -21.7 & & & & 3640-3360 cal. вс & $3650-3615$ cal. BC \\
\hline OxA-13206* & $\begin{array}{l}\text { FSA 4, ox skull from a discrete, } \\
\text { deliberate, deposit beneath } \\
\text { the flint cairn. The specimen is } \\
\text { very soiled and may have been } \\
\text { brought from elsewhere or } \\
\text { exhumed before deposition }\end{array}$ & $4877 \pm 37$ & -20.8 & & & & 3780-3530 cal. вс & 3665-3635 cal. вС \\
\hline OxA-13326* & $\begin{array}{l}\text { FSA 5, ox vertebra from an } \\
\text { articulated vertebral column } \\
\text { and ribs deposited just above } \\
\text { the primary silt in the ditch }\end{array}$ & $4757 \pm 39$ & -21.7 & & & & 3650-3370 cal. вс & $\begin{array}{l}3635-3495 \text { cal. } \text { BC at } \\
79 \% \text { probability or } \\
3430-3375 \text { cal. } \text { BC at } \\
16 \% \text { probability }\end{array}$ \\
\hline OxA-12277 & $\begin{array}{l}\text { FS 2, disarticulated human left } \\
\text { femur from an adult male in } \\
\text { bone group A1 of the mortuary } \\
\text { deposit }\end{array}$ & $4971 \pm 31$ & -20.6 & 9.4 & 3.2 & & 3910-3690 cal. вс & $\begin{array}{l}3895-3880 \text { cal. } B C \\
\text { at } 2 \% \text { probability or } \\
3800-3660 \text { cal. } B C \text { at } \\
93 \% \text { probability }\end{array}$ \\
\hline OxA-13174* & $\begin{array}{l}\text { FS 4, disarticulated human left } \\
\text { femur from an adult male in } \\
\text { bone group A1 of the mortuary } \\
\text { deposit }\end{array}$ & $5075 \pm 40$ & -20.7 & 9.2 & 3.3 & & 3990-3780 cal. вс & 3965-3780 cal. вС \\
\hline OxA-12278 & $\begin{array}{l}\text { FS 6, disarticulated human } \\
\text { left femur from a sub-adult in } \\
\text { bone group A1 of the mortuary } \\
\text { deposit }\end{array}$ & $5021 \pm 31$ & -20.6 & 9.2 & 3.2 & & 3950-3700 cal. вс & $\begin{array}{l}3945-3830 \text { cal. } \text { BC at } \\
47 \% \text { probability or } \\
3825-3705 \text { cal. BC at } \\
48 \% \text { probability }\end{array}$ \\
\hline OxA-14480 & $\begin{array}{l}\text { FL 1, disarticulated human left } \\
\text { femur shaft from a probable } \\
\text { adult male in bone group A2 of } \\
\text { the mortuary deposit }\end{array}$ & $4865 \pm 39$ & -20.9 & 9.6 & 3.5 & & $3780-3530$ cal. вс & 3705-3645 cal. вс \\
\hline GrA-23195 & \multirow{2}{*}{$\begin{array}{l}\text { FS 8.2, disarticulated human } \\
\text { left femur from an adult } \\
\text { female in bone group A2 of the } \\
\text { mortuary deposit }\end{array}$} & $4955 \pm 45$ & -21.8 & & & \multirow{2}{*}{$\begin{array}{l}4955 \pm 31 \\
T^{\prime}=0.0 \\
T^{\prime}(5 \%)= \\
3.8 ; v=1\end{array}$} & \multirow[t]{2}{*}{ 3900-3690 cal. вс } & \multirow[t]{2}{*}{ 3730-3650 cal. вс } \\
\hline OxA-13185* & & $4955 \pm 42$ & -20.6 & 8.9 & 3.2 & & & \\
\hline GrA-28219 & $\begin{array}{l}\text { FL 2, disarticulated human left } \\
\text { femur shaft from a possible } \\
\text { female in bone group A2 of the } \\
\text { mortuary deposit }\end{array}$ & $5050 \pm 50$ & -21.3 & & & & 3990-3700 cal. вс & $\begin{array}{l}3960-3755 \text { cal. } \text { BC at } \\
89 \% \text { probability or } \\
3745-3710 \text { cal. } B C \text { at } \\
6 \% \text { probability }\end{array}$ \\
\hline
\end{tabular}


Table 1. (cont.)

\begin{tabular}{|c|c|c|c|c|c|c|c|c|}
\hline $\begin{array}{l}\text { Laboratory } \\
\text { no. }\end{array}$ & Sample no. and material & $\begin{array}{c}\text { Radiocarbon } \\
\text { age (вР) }\end{array}$ & $\begin{array}{l}\delta^{13} C \\
(\% o)\end{array}$ & $\begin{array}{l}\delta^{15} \mathrm{~N} \\
(\% \circ)\end{array}$ & $\begin{array}{l}\text { C:N } \\
\text { ratio }\end{array}$ & $\begin{array}{l}\text { Weighted } \\
\text { mean (вр) }\end{array}$ & $\begin{array}{l}\text { Calibrated date } \\
\text { range }(95 \% \\
\text { confidence) }\end{array}$ & \begin{tabular}{|l|} 
Posterior density \\
estimate $(95 \%$ \\
probability unless \\
otherwise stated)
\end{tabular} \\
\hline OxA-12279 & $\begin{array}{l}\text { FS 11, disarticulated human left } \\
\text { femur from an adult male in } \\
\text { bone group B of the mortuary } \\
\text { deposit }\end{array}$ & $4857 \pm 31$ & -20.8 & 9.6 & 3.2 & & 3780-3530 cal. вс & $3700-3645$ cal. вС \\
\hline GrA-28174 & $\begin{array}{l}\text { FL 3, disarticulated human } \\
\text { left femur from an older sub- } \\
\text { adult in bone group B of the } \\
\text { mortuary deposit }\end{array}$ & $4940 \pm 45$ & -21.9 & & & & 3910-3640 cal. вс & 3725-3650 cal. BC \\
\hline OxA-12280 & $\begin{array}{l}\text { FS 14, disarticulated human left } \\
\text { femur from an adult male in } \\
\text { bone group B of the mortuary } \\
\text { deposit }\end{array}$ & $4991 \pm 32$ & -20.4 & 8.5 & 3.1 & & 3940-3700 cal. вс & 3735-3650 cal. BC \\
\hline GrA-28175 & $\begin{array}{l}\text { FL } 4 \text {, disarticulated human left } \\
\text { femur from an adult male in } \\
\text { bone group B of the mortuary } \\
\text { deposit }\end{array}$ & $4850 \pm 45$ & -21.1 & & & & 3780-3520 cal. вс & $3705-3645$ cal. BC \\
\hline GrA-28207 & $\begin{array}{l}\text { FL 5, disarticulated human left } \\
\text { femur from an adult female in } \\
\text { bone group B of the mortuary } \\
\text { deposit }\end{array}$ & $4760 \pm 50$ & -21.4 & & & & 3690-3370 cal. вс & - \\
\hline GrA-28208 & $\begin{array}{l}\text { FL 6, disarticulated human } \\
\text { left femur from an unsexed } \\
\text { adult in bone group B of the } \\
\text { mortuary deposit }\end{array}$ & $4940 \pm 50$ & -21.5 & & & & 3940-3630 cal. вс & $3725-3650$ cal. вС \\
\hline OxA-13186* & $\begin{array}{l}\text { FS 24.2, human right ulna from } \\
\text { an adult female (Individual 1) } \\
\text { in bone group C whose bones } \\
\text { were arranged to give the } \\
\text { appearance of articulation }\end{array}$ & $4824 \pm 39$ & -20.4 & 10.2 & 3.2 & $\begin{array}{l}4838 \pm 31 \\
T^{\prime}=0.3 \\
T^{\prime}(5 \%)= \\
3.8 ; v=1\end{array}$ & 3690-3530 cal. вс & $3660-3635$ cal. BC \\
\hline GrA-28290 & $\begin{array}{l}\text { FL 7, human left femur from } \\
\text { adult female (Individual 1) in } \\
\text { bone group C, one of several } \\
\text { fragmentary bones from the } \\
\text { same skeleton arranged to give } \\
\text { the appearance of articulation }\end{array}$ & $4860 \pm 50$ & -21.2 & & & & & \\
\hline OxA-14458 & $\begin{array}{l}\text { FL 8, human left femur } \\
\text { from probable adult female } \\
\text { (individual 2) in bone group } \\
\text { C, one of several fragmentary } \\
\text { bones from the same } \\
\text { skeleton arranged to give the } \\
\text { appearance of articulation }\end{array}$ & $4859 \pm 35$ & -20.7 & 9.4 & 3.2 & & $3780-3530$ cal. вс & 3665-3635 cal. вС \\
\hline GrA-23183 & \multirow[b]{2}{*}{$\begin{array}{l}\text { FS 26, human right femur from } \\
\text { an adult female in bone group } \\
\text { D, one of several bones from } \\
\text { the same skeleton arranged } \\
\text { to give the appearance of } \\
\text { articulation }\end{array}$} & $4950 \pm 50$ & -21.3 & & & \multirow{2}{*}{$\begin{array}{l}4878 \pm 26 \\
T^{\prime}=2.9 \\
T^{\prime}(5 \%)= \\
3.8 ; v=1\end{array}$} & \multirow[t]{2}{*}{ 3780-3550 cal. вс } & \multirow[t]{2}{*}{ 3665-3635 cal. вС } \\
\hline OxA-12281 & & $4850 \pm 31$ & -20.7 & 9.6 & 3.2 & & & \\
\hline OxA-13329* & $\begin{array}{l}\text { FS 28, disarticulated human } \\
\text { tibia shaft fragment displaying } \\
\text { taphonomic evidence of } \\
\text { perimortem fragmentation } \\
\text { from bone group B }\end{array}$ & $4894 \pm 39$ & -20.3 & 9.2 & 3.2 & & 3790-3540 cal. вс & $3710-3650 \mathrm{cal}$. BC \\
\hline OxA-13187* & $\begin{array}{l}\text { FS 29, disarticulated human } \\
\text { tibia shaft displaying } \\
\text { taphonomic evidence of } \\
\text { perimortem fragmentation } \\
\text { from bone group B }\end{array}$ & $4932 \pm 34$ & -20.6 & 9.6 & 3.4 & & 3790-3640 cal. вс & $3720-3650 \mathrm{cal}$. BC \\
\hline
\end{tabular}




\begin{tabular}{|c|c|}
\hline Ditch silting & OxA-13326 \\
\hline \begin{tabular}{l} 
Fuild_barrow \\
Flint cairn, hides, and base of \\
barrow ditch \\
\cline { 2 - 2 } \\
Oll human bone \\
OxA 13206
\end{tabular} \\
\hline
\end{tabular}

Figure 4. Summary of the prior information incorporated in the chronological model shown in Figure 5. The stratigraphic relationships between samples are shown with the earliest at the bottom, and the solid bar down the left-hand side represents a uniformly distributed phase of activity. antler and one charred oak branch or small root. All the samples of human bone, and the ox skull, come from the mortuary deposits. The fragment of oak appears to have been part of the 'mortuary structure' (Ashbee 1966, 8). One result was obtained from an ox metapodial, part of the deposit of bone which formed three articulating ox feet from the surface of the flint cairn. The tip of a red deer antler and an ox vertebra from an articulated vertebral column were dated from the flanking ditch silts.

The results are conventional radiocarbon ages (Stuiver \& Polach 1977). The calibrated date ranges provided in Table 1 have been calculated using the maximum intercept method (Stuiver \& Reimer 1986); all other distributions are based on the probability method (Stuiver \& Reimer 1993). All results have been calibrated using OxCal version 3.10 (Bronk Ramsey 1995; 1998; 2001) and data from Reimer et al. (2004).

The first sample from Fussell's Lodge was dated by the British Museum Radiocarbon Laboratory in the pioneering era of radiocarbon measurement (Barker \& MacKey 1959). The sample was prepared as described by Barker (1953) and dated using gas proportional counting of acetylene (Barker \& MacKey 1968). Nine bone and antler samples were dated by the Centre of Isotope Research at the Rijksuniversiteit Groningen in 2003 and 2005. They were processed and measured as described by AertsBijma et al. $(1997 ; 2001)$ and van der Plicht et al. (2000). The original series of samples dated at the Oxford Radiocarbon Accelerator Unit in 2001 was processed using the gelatinization protocol described by Bronk Ramsey et al. (2000). Following the discovery in the laboratory of a contamination problem associated with this method, in nine cases the contaminated material was re-processed, graphitized, and dated, as described by Bronk

Figure 5. Probability distributions of dates from Fussell's Lodge, incorporating the interpretation of the site sequence suggested by Ashbee (1966). The format is identical to that in Figure 3. The large square brackets down the left-hand side and the OxCal keywords define the overall model exactly. 
Ramsey et al. (2004a). These results are denoted by an asterisk in Table 1. All the other samples were processed using collagen extraction (Law \& Hedges 1989; Hedges et al. 1989), followed by the revised gelatinization and filtration protocol described by Bronk Ramsey et al. (2004a), and dated by AMS as outlined in Bronk Ramsey et al. (2004b).

\section{Interpretations}

Taking account of the varied interpretations of the structures and sequences at Fussell's Lodge long barrow, it is possible to build a number of different models for the chronology of the monument. We have chosen to present three of these in detail. The first of these follows the interpretation of the archaeological evidence presented by Ashbee (1966) (Figs. 4-5). The second is inspired by Kinnes (1992) but adds the variation, already noted above, of successive parts in the mortuary structure (Figs. 6-8). The third is in turn a variant on the second model, allowing for both continued access to the mortuary area until the barrow was built, and the incorporation of human remains

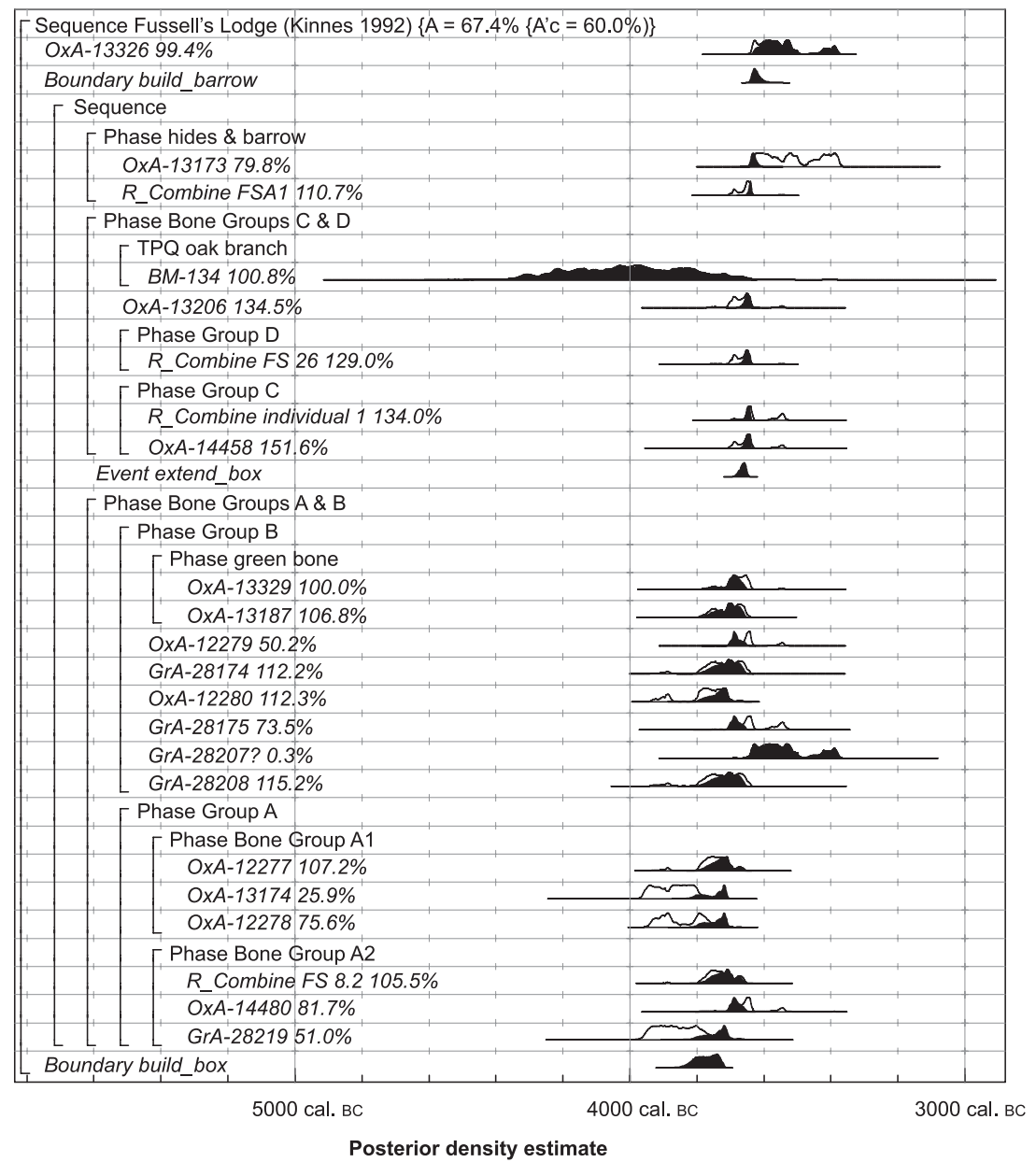

\begin{tabular}{|c|}
\hline Ditch silting OxA-13326 \\
\hline build_barrow \\
\hline $\begin{array}{l}\text { Flint cairn, hides, and base of } \\
\text { barrow ditch }\end{array}$ \\
\hline Bone Groups C \& D \\
OxA-13206 \\
TPQ BM-134 \\
\\
\hline extend_box \\
\hline Bone Groups A1, A2, \& B \\
\hline \\
\hline \\
\hline
\end{tabular}

Figure 6. Summary of the prior information incorporated in the chronological model shown in Figures 7 and 8. The stratigraphic relationships between samples are shown with the earliest at the bottom, and the solid bar down the left-hand side represents a uniformly distributed phase of activity.

Figure 7. Probability distributions of dates from Fussell's Lodge, incorporating the interpretation of the site sequence suggested by Kinnes (1992). The format is identical to that in Figure 3. The large square brackets down the left-hand side and the OxCal keywords define the overall model exactly. 


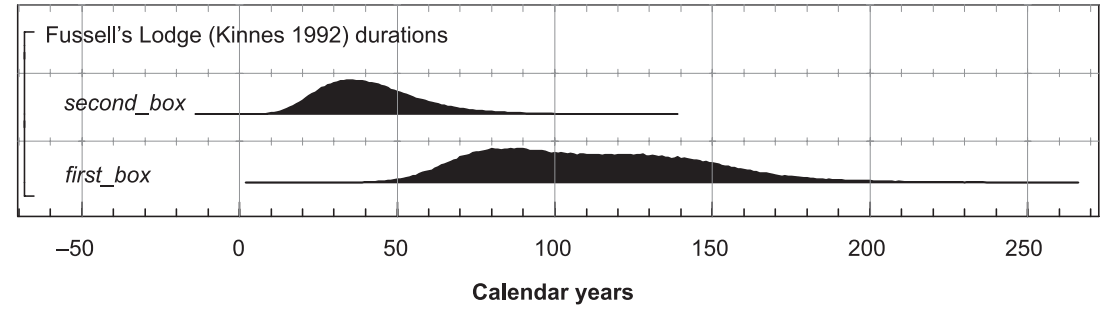

Figure 8. Probability distributions of number of years during which various activities occurred at Fussell's Lodge long barrow, derived from the model shown in Figure 5.

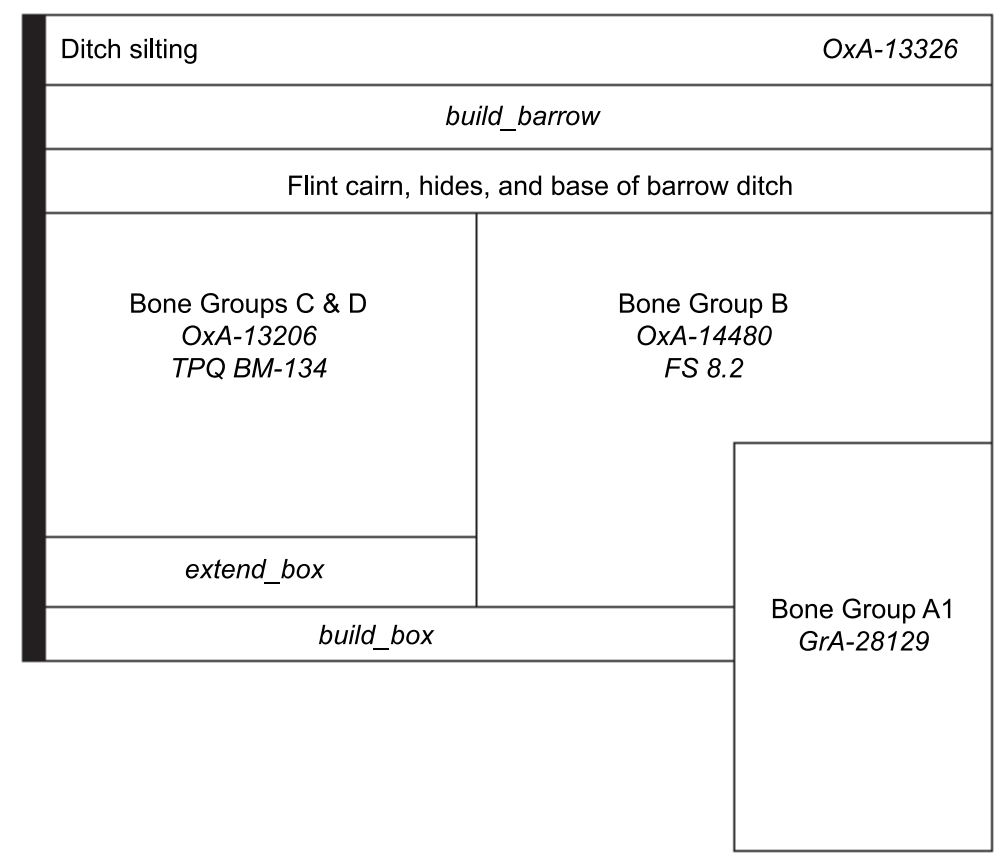

Figure 9. Summary of the prior information incorporated in the chronological model shown in Figures 10 and 11. The stratigraphic relationships between samples are shown with the earliest at the bottom, and the solid bar down the left-hand side represents a uniformly distributed phase of activity.

older (and perhaps substantially older) than the actual building of the mortuary structure (Figs. 9-11).

A summary of the archaeological information included in the first model, which follows Ashbee's (1966) interpretation of the site sequence as essentially a unitary construction, is shown in Figure 4. All the bone samples from the mortuary deposits are earlier than the construction of the mortuary structure itself, the construction of the trapezoidal timber enclosure and the building of the earthen barrow. The actual chronological model is shown in Figure 5. This suggests that the monument was constructed in 3645-3475 cal. вС (95\% probability; build_barrow), most probably in the latter decades of the thirty-seventh century cal. вс (see the bi-modal distribution build_barrow in Fig. 5). ${ }^{1}$

Figure 6 shows a summary of the archaeological information included in the second model, which is inspired by the interpretation of the sequence proposed by Kinnes (1992). That separated Pit $C$ from a primary linear zone with a 'chamber' of some kind containing Bone Groups A1, A2, $\mathrm{B}, \mathrm{C}$ and $\mathrm{D}$. We have modified this interpretation by suggesting that a first, inner, part of the mortuary structure consisted of Pits A and B, with Bone Groups A1, A2 and B. This was followed by a second, later, addition between Pit B and the entrance (but without $P$ it $C$ ), and containing Bone Groups C and D. We view Pit C, following Kinnes (1992, 86), as part of closure and mound construction.

The chronological model incorporating this interpretation of the archaeological record is shown in Figure 7. This suggests that the construction of the primary phase of the mortuary structure (between Pits A and B) occurred in 3840-3710 cal. BC (95\% probability; build_box), probably in the first half of the thirty-eighth century cal. вс (3805-3730 cal. BC: $68 \%$ probability; build_box: Fig. 7). The mortuary structure was extended from Pit B to the entrance of the trapezoidal timber enclosure in 3685-3645 cal. BC (95\% probability; extend_box), probably in the 3660s or the 3650s cal. вс (Fig. 7). The barrow was constructed, along with Pit C (closing access to the mortuary structure), in 3645-3590 cal. вС (95\% probability; build_barrow), probably in the 3630 s or 3620 s cal. вс (Fig. 7). ${ }^{2}$

According to this model, the primary phase of the mortuary structure between Pits A and B was in use for between 50 and 180 years $(95 \%$ probability; first_box: Fig. 8), probably for four to six generations (71.2\% probable: see discussion in Whittle, Barclay et al. this issue). The extension to this structure was in use for 10-75 years (95\% probability; second_box: Fig. $8)$, probably for only one or two generations (73.5\% probable: see discussion below).

It should be noted that individual FL 5 in Bone Group B produced a radiocarbon determination (GrA-28207) which is in poor agreement with this model, and has been excluded from the analysis. This individual is rather later than the other dated people in Bone Group B. This suggests that, contrary to the 
model shown in Figure 7, access to the distal portion of the mortuary deposits may have been maintained after the construction of the extension which includes Bone Groups C and D.

The first model presented in this section interpreted all the human remains from the mortuary deposit as secondary burials, defleshed bones gathered up from elsewhere and placed in the mortuary structure when the monument was built. All these remains are therefore considered in some sense ancestral in this interpretation. In contrast, all the human remains in the second model above are considered to be later than the initial construction of the mortuary structure. Skeletons were reordered but went into the linear mortuary zone (in the terms of Kinnes 1992, 83, 103) as complete entities. The third model takes a middle course, suggesting both that some individuals were recently dead when their remains were placed in the mortuary area and that other bones may already have been old when gathered up for interment there. In the other monuments and mortuary assemblages reported in this series of papers, it has been possible to compare the dates from both articulated and disarticulated human remains, to determine whether the latter are significantly older. That is not possible with the disarticulated assemblage at Fussell's Lodge, even with Bone Groups C and D, since they are not single individuals.

The 17 dated individuals from the mortuary structure have not provided statistically consistent radiocarbon measurements $\left(T^{\prime}=73.8 ; T^{\prime}(5 \%)=26.3\right.$; $v=16$ : Ward \& Wilson 1978), and so must have died over a period of time. There is some suggestion of a chronological progression in the mortuary area, with the earliest remains lying furthest away from the entrance of the trapezoidal timber enclosure (Bone Groups A1, A2), and the latest closest to that (Bone Groups C, D). As already noted above, Kinnes had allowed for the possibility of successive placings of this kind (1992, 104). Bone Groups $C$ and D represent more complete individuals than in Bone Groups A and B, consistent with their having been less modified or manipulated after insertion into the mortuary structure. The radiocarbon measurements on the three dated individuals from Bone Groups $C$ and D are statistically consistent $\left(T^{\prime}=1.0 ; T^{\prime}(5 \%)=6.0 ; v=2\right)$, suggesting that these deposits may have been formed over a relatively short period of time. The chronological progression along the linear mortuary zone is not absolute but, rather, a general trend. Individuals FL 1 from Bone Group A2 and FL 5 from Bone Group B both appear to be rather later than the majority of individuals at the distal end of the mortuary structure. Equally, individuals FS 4 from Bone Group A1 and FL 2 from Bone Group A2 seem rather earlier than the other dated individuals from the mortuary deposits. This chronological succession may have implications for the question of access to the mortuary deposits during the period of their placement, which is discussed further below.

On the basis of the osteological evidence outlined above (and see Wysocki \& Whittle in prep.), we anticipate the presence of 'curated' ancestral remains within the mortuary deposits at Fussell's Lodge, though it is a matter for subtle statistical interpretation to determine which individuals can be identified as candidates for such ancestral status. The spatial layout, the high incidence of hand and foot bones (21.5\% of the expected number), and the statistical consistency of the radiocarbon measurements from Bone Groups $\mathrm{C}$ and $\mathrm{D}$, all suggest that such 'ancestors' are not present in these groups. The much greater extent of re-ordering of the remains in Bone Groups A and B, along with the lack of hand and foot bones $(5.9 \%$ of the expected number) and the statistical inconsistency of the radiocarbon measurements $\left(T^{\prime}=55.9 ; T^{\prime}(5 \%)=22.4 ; v=13\right)$, suggest that ancestral remains are far more likely to have been present in this inner part of the mortuary structure. Can these be identified on the basis of the radiocarbon determinations? The dated individuals in Bone Group A do not form a statistically consistent group $\left(T^{\prime}=18.6 ; T^{\prime}(5 \%)=11.1 ; v=5\right)$, although those in Bone Group A1 do, as is also the case with the measurements from individuals in Bone Group A2 except for individual FL 2 (GrA-28219). This individual, along with those from Bone Group A1, appears to be rather older than the other individuals in Bone Group A. The dated individuals in Bone Group B also do not form a statistically consistent group $\left(T^{\prime}=21.2 ; T^{\prime}(5 \%)=14.1\right.$; $v=7$ ), although in this case individual FL 8 (GrA-28207) forms a clear later outlier. It should be noted that the samples showing 'green bone' fracture morphology gave radiocarbon measurements that are statistically consistent with the main group of individuals dated from Bone Group B $\left(T^{\prime}=12.3 ; T^{\prime}(5 \%)=12.6 ; v=6\right)$.

On these rather tenuous grounds, the archaeological interpretation summarized in Figure 9 has been incorporated in the third model. This chronological model is shown in Figure 10. This suggests that the construction of the primary mortuary structure occurred in 3755-3660 cal. вС (95\% probability; build_box: Fig. 10), probably in the last quarter of the thirty-eighth century cal. вс or the first half of the thirty-seventh century cal. вс. The mortuary structure was extended in 3675-3640 cal. BC (95\% probability; extend_box: Fig. $10)$ and the barrow was built in 3650-3605 cal. вС (95\% probability; build_barrow: Fig. 10) probably in the 3630s or 3620s cal. вс. 


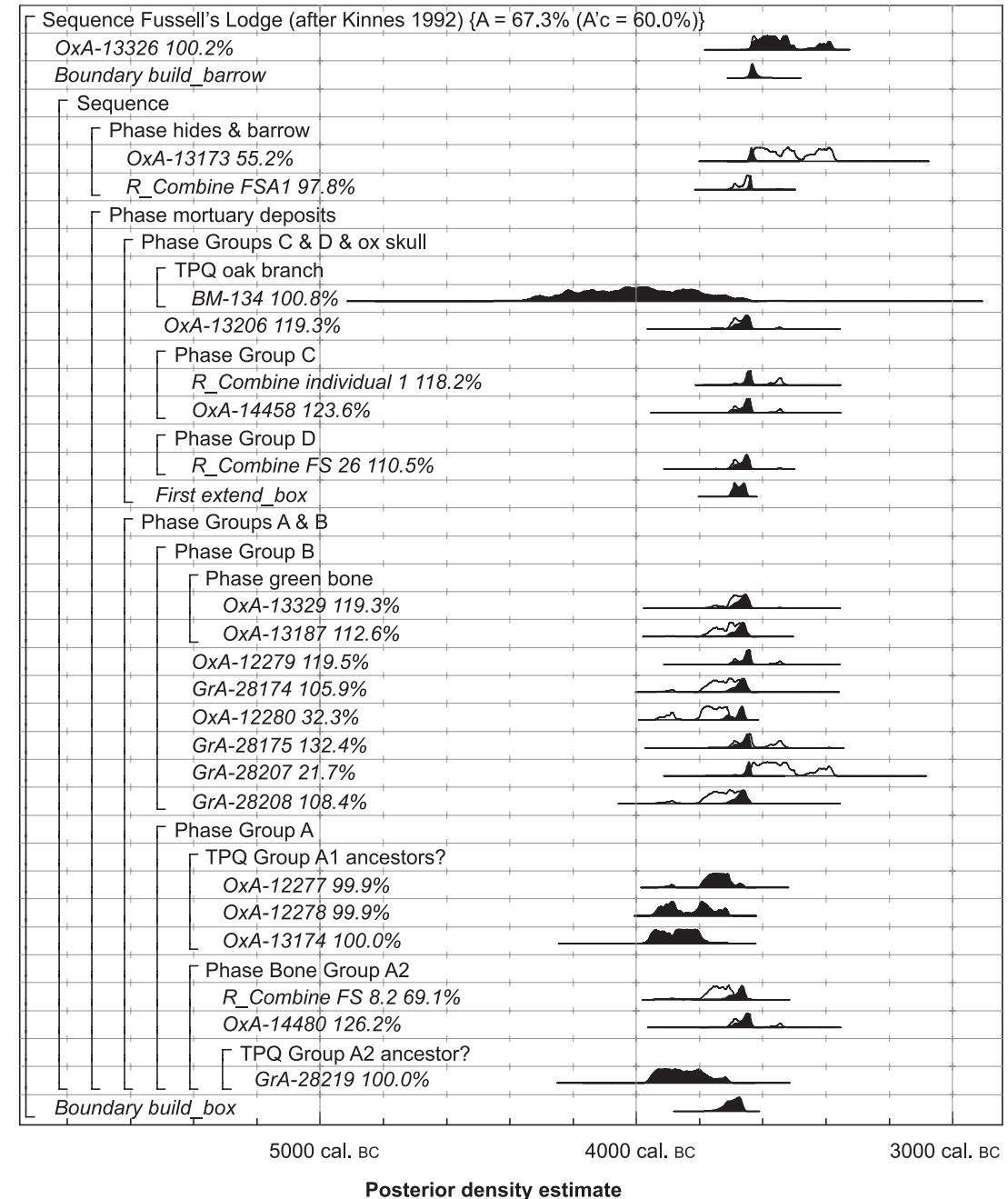

Figure 10. Probability distributions of dates from Fussell's Lodge, incorporating the interpretation of the site sequence suggested by Kinnes (1992), with access to the boxes maintained until the construction of the barrow mound, and the interpretation that the dated bones in Bone Group A1 and individual FL 2 in Bone Group 2 might be older than the construction of the monument. The format is identical to that in Figure 3. The large square brackets down the left-hand side and the OxCal keywords define the overall model exactly.

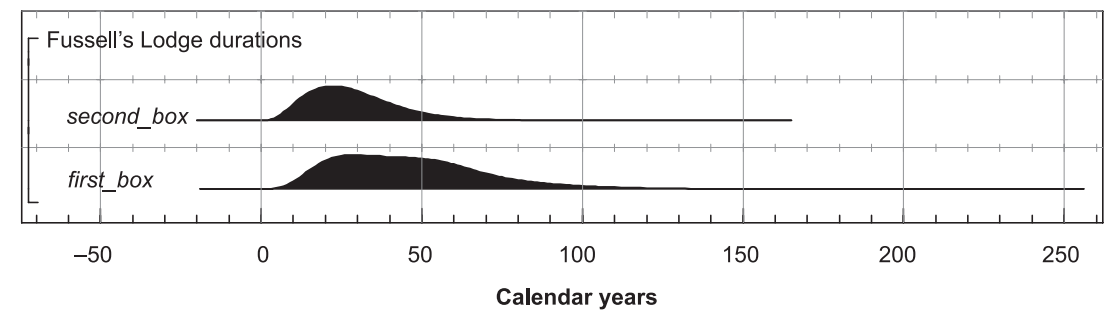

Figure 11. Probability distributions of number of years during which various activities occurred at Fussell's Lodge long barrow, derived from the model shown in Figure 10.
This third model suggests that the initial mortuary structure was in use for 5-95 years (95\% probability; first_box: Fig. 11), for between one and three generations (89.2\% probable). Burials continued in the extended structure for between 5-60 years (95\% probability; second_box: Fig. 11$)$, probably for one or two generations (92.1\% probable).

The posterior density estimates for the constructional events at Fussell's Lodge from the three models presented here are shown in Figure 12. It can be seen that all three models are consistent in suggesting that the construction of the barrow occurred in the second half of the thirty-seventh century cal. $\mathrm{BC}$, probably in the 3630 s or 3620 s cal. BC. As the first model envisages a unitary construction, this is the only estimate provided by it. The second and third models are also consistent in suggesting that the mortuary structure was extended (or at least that Bone Groups C and D were deposited) in the second quarter of the thirty-seventh century cal. $\mathrm{BC}$, probably in the 3660s or 3650s cal. вс. The only substantive difference between the three models concerns the estimated date of the construction of the primary mortuary structure. This can only be dated from radiocarbon determinations on the mortuary deposits. Depending on archaeological and osteological interpretations of this material, either this structure was built in the earlier part of the thirtyeighth century cal. вс (second model, where all the dated individuals died after the structure had been built) or in the decades around $3700 \mathrm{cal}$. $\mathrm{BC}$ (third model, where some of this material is regarded as ancestral), or in the second half of the thirty-seventh century cal. BC (first model, where all the human material is regarded as secondary, and the mortuary structure was built at effectively the same time as the barrow mound) (Fig. 12).

All three chronological models show good overall agreement (Bronk 
Ramsey 1995; Figs. 5, 7 \& 10), and so each archaeological interpretation conforms with the radiocarbon evidence. On the basis of the statistical methodology which is currently and routinely available, it is not possible to determine which of these models is more probable (see also Bayliss et al. this issue, where the question of model choice is discussed; and see also the discussion below). The spread of the radiocarbon determinations from the mortuary deposits may suggest that the entire space continued to be accessible until the barrow was constructed. This is suggested by the poor agreement of GrA-28207 with the interpretation that the areas between Pits A and B was closed off on construction of the extension containing Bone Groups $\mathrm{C}$ and D (Bronk Ramsey 1995; A = 2.9\%). The general chronological progression within these mortuary deposits

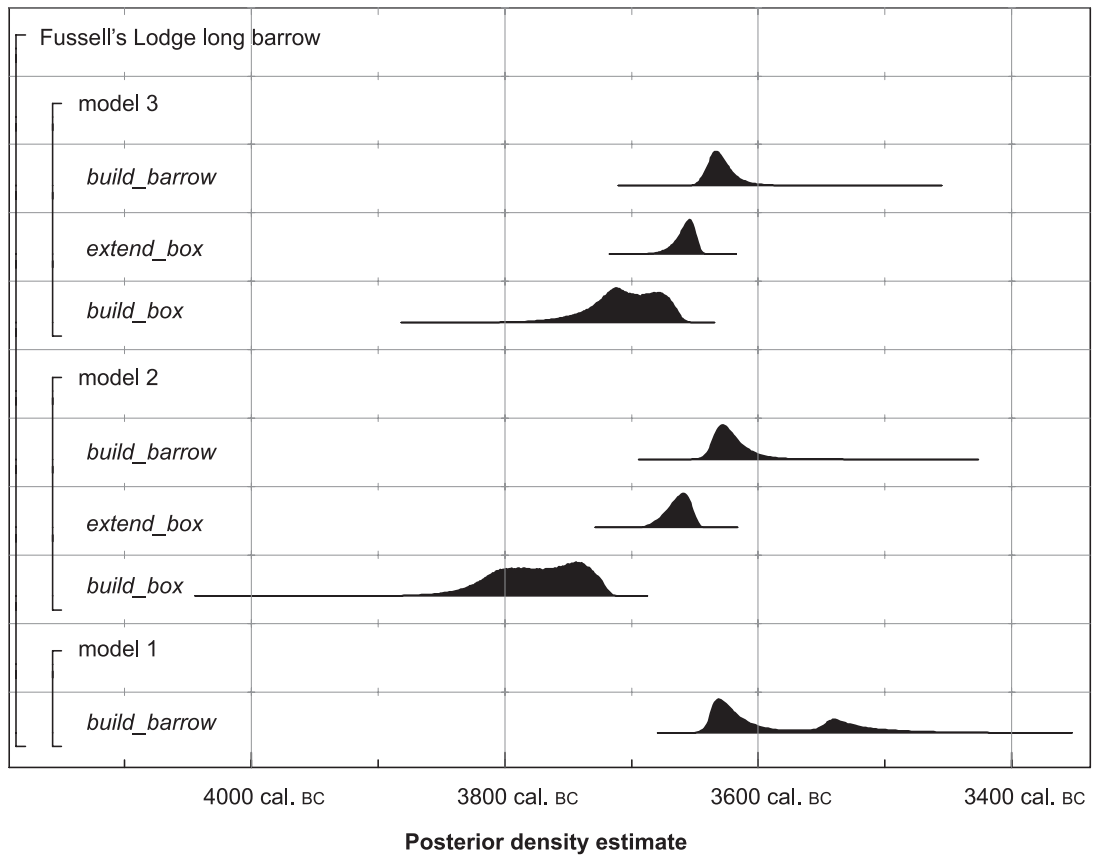

Figure 12. Posterior density estimates for the date of constructional events at Fussell's Lodge long barrow, according to model 1 (Figs. 4-5), model 2 (Figs. 6-8), and model 3 (Figs. 9-11). shown, with the earlier material more likely to be placed at the distal end of the linear mortuary zone and more recent material at the proximal end, may suggest that this access was from the porch and entrance of the trapezoidal timber enclosure. The form that this linear zone may have taken is discussed below.

The lack of articulated human bone in the mortuary deposits at Fussell's Lodge means that the radiocarbon determinations do not inform the debate about whether ancestral material was placed in the monument. Alternative models which show good overall agreement have been produced for a range of archaeological readings of this issue. Even when on archaeological grounds it is considered desirable to attempt the identification of particular individuals as potentially ancestral material, the radiocarbon evidence is far from certain. Herein lies the potential importance of the green bone noted and discussed above for the interpretation of the taphonomy of the mortuary deposits. The green bones must have been fresh when they were fragmented, and because of the number of very small fragments it is unlikely that they were collected up and brought in from elsewhere. As the radiocarbon measurements on this material are statistically consistent with those from the main group of 'dry bone' individuals dated from Bone Group B (see above), then at least some of the material in the mortuary deposits must have gone in fresh. This may suggest that Ashbee's model (1966; model 1; Fig. 5), in which all the mortuary deposits are interpreted as secondary, is less plausible.

Other points of archaeological debate have been resolved by the radiocarbon dating programme. It is clear that the ox skull at the proximal end of the mortuary deposits does not come from the same animal as the hide ${ }^{3}$ inferred from the ox foot bones over the flint cairn, which could have been draped over it $\left(T^{\prime}=5.8 ; T^{\prime}(5 \%)=3.8 ; v=1\right)$. It is also clear that this hide, and potentially the burning event in which one of the foot bones from it was charred (this point is discussed further below), date to the episode of barrow construction. This is shown by the poor agreement of models in which the hide on top of the flint cairn (OxA-13173) is interpreted to be earlier than the barrow construction as dated by the antler tip from the base of the primary ditch fill (FSA 1; e.g. $A_{\text {overall }}=40.1 \%$ in this variant of model 2). The radiocarbon measurements from the hide and from the antler tip are also statistically indistinguishable $\left(T^{\prime}=6.5 ; T^{\prime}(5 \%)=7.8 ; v=3\right)$.

Turning to the number of years over which the various activities may have occurred at the Fussell's Lodge long barrow, the three models provide rather different estimates. The first model suggests essentially unitary activity, with older human material incorporated from elsewhere in a single act of deposition. The second model suggests that the primary mortuary 


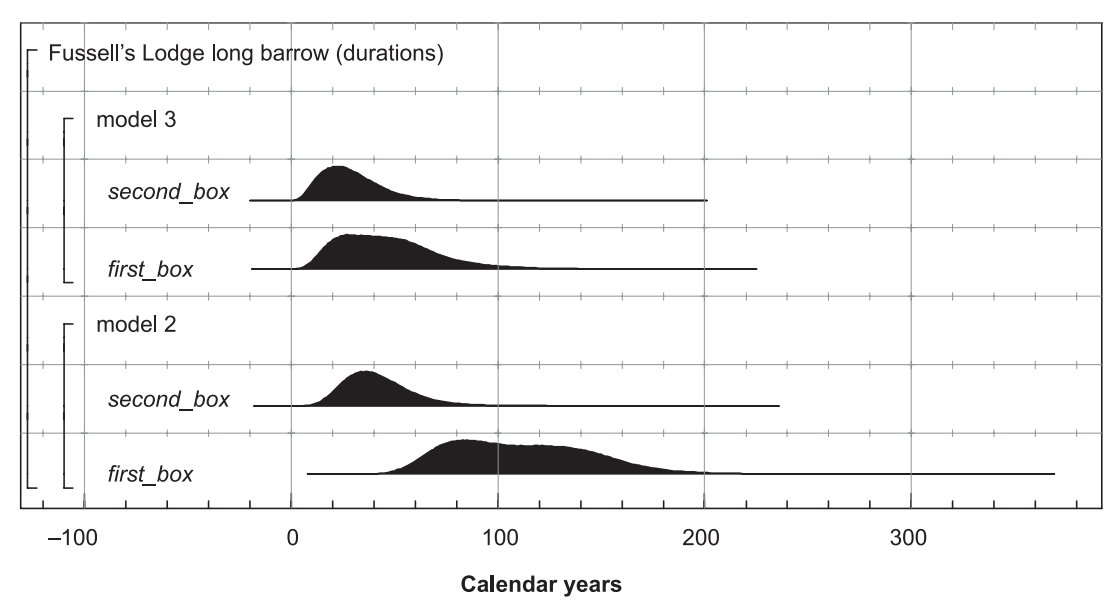

Figure 13. Probability distributions of number of years during which various activities occurred at Fussell's Lodge long barrow, derived from the models 2 (Figs. 6-8) and 3 (Figs. 9-11).

structure was in use for a century or so, although the third model suggests that deposition in this primary mortuary area was shorter-lived (Fig. 13). Both these interpretive models agree in suggesting that the use of the extended mortuary structure (Bones Groups C \& D) spanned only a generation or two.

\section{Discussion}

We have adapted the title of this paper from Shakespeare's Macbeth, when Macbeth himself, hearing publicly the news of Duncan's death, declares, 'Had I but died an hour before this chance/I had lived a blessed time; for, from this instant/there's nothing serious in mortality'. We like the play between the senses of 'mortality' as being alive and the condition of being subject to death. They seem an appropriate backdrop as we move to discuss the many implications of the chronological models derived from the dating project on the Fussell's Lodge long barrow. Four main topics will be covered: dates at local and regional scales; the structural development of the barrow; mortuary rites and their meaning; and the contribution of these results to wider histories of the Neolithic in southern Britain.

It has long been suggested that earthen long barrows contain potentially long sequences of development, from their initial mortuary structures to the final completion and closure represented by the mounds formed principally by material derived from substantial flanking ditches (Piggott 1966; Ashbee 1970; Kinnes 1992; Thomas 1999). There is little need in this context to rehearse the well known examples, complementing Fussell's Lodge itself, from southern Britain up to eastern Scotland, which show this. It has not, however, been possible up to now to put very exact timescales on this kind of recurrent constructional and ritual history. Nor has it generally been possible up till now to give precise dates for the earthen long barrow phenomenon as a whole, in any of the regions of Britain where it occurs. Kinnes (1992, 115-29) drew together the radiocarbon evidence (as well as the artefactual evidence) available at the start of the 1990s, and that has changed little since (e.g. Scarre et al. 2003). Most sites have been dated with very few samples and, as Kinnes pithily if a little too pessimistically summarized (1992, 120), 'most offer no more than a confirmation of Neolithic date, a conclusion already achieved before the application of this technique'. More generously, we could take most results to indicate a position in the second and third quarters of the fourth millennium cal. $\mathrm{BC}$, without normally being able to offer more precision than that. More recently, the timbers of the primary mortuary box of the Haddenham long barrow have provided a floating tree-ring sequence wigglematched by radiocarbon dating to the second half of the thirty-seventh or the first half of the thirty-sixth centuries cal. вС (Hodder \& Shand 1988; Morgan 2006; Chris Evans pers. comm.). The long barrows from Raunds and Hambledon Hill have also now been well dated, to the thirty-eighth/thirty-seventh and thirty-seventh centuries cal. вс respectively (Harding \& Healy forthcoming; Healy 2004; Frances Healy pers. comm.).

The first significance of the Fussell's Lodge results is therefore to add another securely derived date for the earthen long barrow phenomenon. All three models agree in placing the Fussell's Lodge barrow construction in the second half of the thirty-seventh century cal. вс, probably in the 3630 s or 3620 s cal. вс. As stressed earlier in this paper, the models differ in their dates for the construction of the primary mortuary structure (which is what is precisely dated at Haddenham, as above). Each of the three models has good internal consistency. We prefer one or other of the variants (models 2 and 3 here) on the scheme proposed originally by Kinnes (1992), and by a short head model 3 , in which there is not only constructional sequence and continued access to the mortuary deposits over a period of time, but also the possibility (argued above on archaeological but not statistical grounds) of the presence of ancestral remains. Our third model takes 
the beginning of activity at Fussell's Lodge long barrow back to the decades around 3700 cal. вс.

Given the lack of precise dating for other earthen long barrows apart from Haddenham, Raunds and Hambledon Hill, it is premature to build too much on these results. They can at least be thought about, however, at both local and regional scales. On the basis of all the models, the earthen barrow at Fussell's Lodge appears to be later than the constructions at Ascott-under-Wychwood and Hazleton, and probably later than that at West Kennet, but earlier than the first phase of Wayland's Smithy (and see Whittle, Bayliss \& Wysocki this issue, p. 115, fig. 4). The monumentalization represented by barrow construction at Fussell's Lodge is therefore likely to have been comparatively late, given the beginnings of such phenomena in the thirty-eighth century cal. $\mathrm{BC}$, as suggested by the other sites reported in this series of papers. The interest in the gathering up of old human remains and/or their concentrated deposition as fresh material in particular places and specific containers, however, is not so much younger than elsewhere (using the results from Ascottunder-Wychwood, for example), and so people living in or at least using the eastern part of Salisbury Plain may not have been out of touch with changes going on elsewhere. There is a local dimension to this agency as well. We noted the location of Fussell's Lodge briefly at the start of this paper. Could its peripheral setting, at least from our map-based perspective, suggest a position and date in local history that showed people east of the River Bourne reacting to what neighbours to the west had already done? It will require further dating of earthen long barrows in the main concentrations of Salisbury Plain to begin to resolve this point. We reserve discussion of wider relationships beyond southern Britain till the final paper (Whittle, Barclay et al. this issue).

The dating programme has usefully highlighted a number of details to do with the nature of the mortuary structure. It was unfortunately not possible to radiocarbon date the trapezoidal timber enclosure, but the archaeological observation of the excavator that it preceded Pit C is central to the view that it is a primary feature. As noted already, there has been much debate about the form which mortuary structures took. Kinnes (1992) has underlined the likely diversity of these settings, and we can observe that the graphic reconstruction proposed for Fussell's Lodge (Ashbee 1970, fig. 34) does not work, since it fails to account for the narrow, contained, linear zone of human remains within the broad skirts of a tent-like and heavy wooden construction. Here, as elsewhere, what may be the really key issue, whatever the form of construction, is whether continued access was possible. The direct evidence from Haddenham for a single wooden lid on an elongated, massive, wooden box (Hodder \& Shand 1988) demonstrates one way in which accessibility could be achieved. Crawling through a narrow, tent-like structure would be another means, more difficult, more likely to disturb already deposited remains, but nonetheless feasible. We can envisage, but do not need to insist upon, substantial posts in Pits A and B, serving to frame a primary linear mortuary zone. Model 3 suggests that this arrangement, whatever its precise form, was still accessible after the putative secondary extension towards the proximal end. And we should note again the spread of the human bone of Group B over the fill of Pit B.

We have shown above that the ox skull and the ox feet are of different age. There is therefore a tradition at the site of incorporating cattle remains, perhaps in both cases in the form of hides, into mortuary deposits and the events surrounding them. Could there have been hide coverings rather than wooden lids over the mortuary deposits? Whatever the answer, this tradition reinforces the impression, given by other similar monuments, of an intimate relationship between people and cattle, which was displayed in the mortuary domain as well as in other contexts (Thomas 1999, 28; cf. Ray \& Thomas 2003; Whittle 2003).

Traces of charring or burning on some of the human remains (Kinnes 1992, 101) and on one of the ox feet, together with the burnt oak dated by BM-134 and the burnt flint and chalk deposit associated with it (Ashbee 1966, 7), all suggest a burning event in the episode of the closure of the mortuary deposit and the construction of the earthen long barrow. Such burning has of course been widely documented and commented on elsewhere (e.g. Kinnes 1992; Thomas 1999), and does not need rehearsing here, but we return to it shortly below in wider discussion of the meanings of the mortuary rites at Fussell's Lodge.

Turning to those wider meanings, we can echo the views of other authors about the potential complexity of the mortuary rites represented at Fussell's Lodge long barrow (e.g. Shanks \& Tilley 1982; Kinnes 1992, 99-100, 103-4; Thomas 1999, 136). We can underline this now, having provided interpretive estimates of timescales in models 2 and especially 3 over which these complex and diverse rites may have been played out. Pulling all the evidence together, we can now ascribe to our preferred date span from around 3700 cal. вс down to the 3630 s or 3620 s cal. вс the following interests, if not obsessions, of a group of people living in or using the eastern part of Salisbury Plain:

- the recognition and gathering up of old human remains; 
- their concentration in a single selected place, in a linear container of some kind, to which continued access remained possible for a while;

- the deposition of selected, freshly dead people into the same container;

- the re-ordering of these human remains, whether originally buried elsewhere or first interred in situ, in terms of at least two categories, separate groupings determined either by date of deposition or by group affiliation or both, and the alignment of body part in relation to the linear axis of the monument (and, for a more complicated view, see again Shanks \& Tilley 1982);

- and the protection or concealment of all this within the confines of a substantial timber enclosure, itself an impressive wooden monument, with the potential capacity to hold large numbers of people.

Such interests may not have been unchanging over the few generations that the timespan of model 3 suggests. The explicit link with cattle is introduced in the phase of the extension of the mortuary zone, and is still of active interest at its closure, as witnessed by the hide draped over the flint cairn, which would presumably have been the most prominent item to be visible in the flames of the burning episode. That coincides with a shift in visual presentation of human remains, with the simulacrum of two articulated people composed by the remains of four individuals. Themes of cattle ownership may be being invoked here, and cattle are a dominant concern at the causewayed enclosures which may have begun in the thirty-seventh century cal. вС (Oswald et al. 2001; Healy 2004; and see also the current English Heritage- and AHRC-funded project to radiocarbon date causewayed enclosures, being carried out by Alasdair Whittle, Frances Healy and Alex Bayliss). These great issues of remembrance, transformation (cf. Fowler 2002), bodily identity, affiliation, and the relationship with and ownership of powerful animals, are all brought to a conclusion, perhaps only in the local context temporarily, in the closure of the mortuary structure and the construction of the earthen barrow, an episode itself further redolent both of transformation (by fire) and of commemoration. What form that remembering took - whether of much older traditions on the European continent or of more recent and even contemporary practices in southern Britain - we discuss further in the last paper (Whittle, Barclay et al. this issue).

This discussion of the meanings of Fussell's Lodge long barrow could continue, but the most important contribution of the dating project overall has been to situate them now within a specific historical context. By this means, but only by this means, we can compare the worldview and agency of those particular few generations (see again Fig. 11 for estimates derived from model 3) with both what had come before and what was to follow. Using again the quotation from Macbeth, perhaps this was a 'blessed time', in which 'renown and grace' were far from dead.

\section{Acknowledgements}

The radiocarbon dating programme reported here was funded by English Heritage. We thank Amanda Chadburn for every assistance. We are grateful to the staff of the Oxford Radiocarbon Accelerator Unit and the Centre of Isotope Research, Rijksuniversiteit Groningen, for dating these samples. The re-analysis of the human bone assemblage was undertaken as part of a project funded by the Leverhulme Trust. We are grateful to Dr Louise Humphrey and Dr Robert Kruszynski of the Department of Palaeontology, Natural History Museum, for access to the collection of human bone and for permission to sample for radiocarbon dating, and to Dr Peter Saunders and Dr Andrew Deathe of the Salisbury and South Wiltshire Museum, for access to the collection of animal bone and for permission to sample for radiocarbon dating. Wendy Hart assisted in the sampling of the later submissions, and we are grateful to Christopher Evans and Frances Healy for information on the dating of other long barrows. Finally, thanks to Andrew David, Jonathan Last, Peter Marshall, Mike Parker Pearson, Joshua Pollard and Julian Thomas, for perceptive and constructive criticism of an earlier draft.

\section{Notes}

1. It is likely that at least some of the bone interred in the barrow was already several centuries old when deposited here. If the interred individuals represent a random sample from previous generations (which we think is unlikely), then the oldest material brought together for burial in the mortuary area is dated to $3840-3710$ cal. BC (95\% probability; build_box: Fig. 7 and see below). In this case, the oldest material was already 85-320 years old (95\% probability) or 105-235 years old (68\% probability).

2. Although we feel that it is likely that the mortuary structure was not constructed at one time (on the evidence of the relationship between Pit $\mathrm{C}$ and the trapezoidal palisade enclosure), an alternative interpretation suggested to us by Julian Thomas is that the mortuary structure was the first construction at the site (i.e. not part of a unitary construction as envisaged by the excavator). Fleshed or semi-fleshed bodies could have been placed in the outer part of the structure in the first instance and then moved and stacked in the inner part once fully defleshed. This would explain the earlier dating for most of the remains in Bone Groups A and B, and the later dates for Bone Groups C and D. This can be regarded as a variant on our model 2 , and produces date estimates for the building of the mortuary structure and the rais- 
ing of the barrow which are practically identical to those produced by model 2 itself.

3. Mike Parker Pearson has pointed out to us, on the basis of his own observations in Madagascar, that the feet do not necessarily represent a hide, but could be offerings detached after sacrifice of an animal. We do not think this interpretation alters any of the models presented here.

\section{References}

Aerts-Bijma, A.T., H.A.J. Meijer \& J. van der Plicht, 1997. AMS sample handling in Groningen. Nuclear Instruments and Methods in Physics Research B 123, 221-5.

Aerts-Bijma, A.T., J. van der Plicht \& H.A.J. Meijer, 2001. Automatic AMS sample combustion and $\mathrm{CO}_{2}$ collection. Radiocarbon 43(2A), 293-8.

Ashbee, P., 1966. Fussell's Lodge long barrow excavations, 1957. Archaeologia 100, 1-80.

Ashbee, P., 1970. The Earthen Long Barrow in Britain. London: Dent.

Atkinson, R.J.C., 1965. Wayland's Smithy. Antiquity 39, 126-33.

Barker, H., 1953. Radiocarbon dating: large-scale preparation of acetylene from organic material. Nature 177, 631-2.

Barker, H. \& J. Mackey, 1959. BM natural radiocarbon measurements I. Radiocarbon 1, 81-6.

Barker, H. \& J. Mackey, 1968. The BM natural radiocarbon measurements V. Radiocarbon 10, 107.

Bass, W.M., 1997. Outdoor decomposition rates in Tennessee, in Forensic Taphonomy: the Postmortem Fate of Human Remains, eds. W.D. Haglund \& M.H. Sorg. Boca Raton (FL): CRC Press, 181-6.

Bayliss, A. \& C. Bronk Ramsey, 2004. Pragmatic Bayesians: a decade integrating radiocarbon dates into chronological models, in Tools for Constructing Chronologies: Tools for Crossing Disciplinary Boundaries, eds. C.E. Buck \& A.R. Millard. London: Springer, 25-41.

Bayliss, A., C. Bronk Ramsey \& F.G. McCormac, 1997. Dating Stonehenge, in Science and Stonehenge, eds. B. Cunliffe \& C. Renfrew. Oxford: British Academy, 39-59.

Bayliss, A., C. Bronk Ramsey, J. van der Plicht \& A. Whittle, this issue. Bradshaw and Bayes: towards a timetable for the Neolithic.

Bronk Ramsey, C., 1995. Radiocarbon calibration and analysis of stratigraphy. Radiocarbon 36, 425-30.

Bronk Ramsey, C., 1998. Probability and dating. Radiocarbon 40, 461-74.

Bronk Ramsey, C., 2001. Development of the radiocarbon calibration program. Radiocarbon 43, 355-63.

Bronk Ramsey, C., P.B. Pettitt, R.E.M. Hedges, G.W.L. Hodgins \& D.C. Owen, 2000. Radiocarbon dates from the Oxford AMS system: Archaeometry datelist 30. Archaeometry 42, 459-79.

Bronk Ramsey, C., T.F.G. Higham, A. Bowles \& R.E.M. Hedges, 2004a. Improvements to the pre-treatment of bone at Oxford. Radiocarbon 46, 155-63.

Bronk Ramsey, C., T. Higham \& P. Leach, 2004b. Towards high precision AMS: progress and limitations. Radiocarbon 46, 17-24.

Brothwell, D.R. \& M.L. Blake, 1966. The human remains from the Fussell's Lodge long barrow: their morphology, discontinuous traits and pathology. Archaeologia 100, 48-63.

Corcoran, J.X.W.P., 1969. The Cotswold-Severn group, 1. Distribution, morphology and artefacts, in Megalithic Enquiries in the West of Britain, eds. T.G.E. Powell, J.X.W.P. Corcoran, F. Lynch \& J.G. Scott. Liverpool: Liverpool University Press, 13-72.

Cox, M. \& L. Bell, 1999. Recovery of human skeletal elements from a recent UK murder enquiry: preservational signatures. Journal of Forensic Sciences 44, 945-50.

Darvill, T.C., 1982. The Megalithic Chambered Tombs of the Cotswold-Severn Region. Highworth: Vorda.

Fowler, C., 2002. Body parts: personhood and materiality in the earlier Manx Neolithic, in Thinking Through the Body: Archaeologies of Corporeality, eds. Y. Hamilakis, M. Pluciennik \& S. Tarlow. New York (NY): Kluwer Academic/Plenum Press, 47-69.

Grigson, C., 1966. The animal remains from Fussell's Lodge long barrow. Archaeologia 100, 63-73.

Harding, J. \& F. Healy, forthcoming. Raunds Area Project: the Neolithic and Bronze Age Landscapes of West Cotton, Stanwick and Irthlingborough, Northamptonshire. London: English Heritage.

Healy, F., 2004. Hambledon Hill and its implications, in Monuments and Material Culture. Papers in Honour of an Avebury Archaeologist: Isobel Smith, eds. R. Cleal \& J. Pollard. East Knoyle: Hobnob Press, 15-38.

Hedges, R.E.M., C.R. Bronk \& R.A. Housley, 1989. The Oxford accelerator mass spectrometry facility; technical developments in routine dating. Archaeometry 31, 99-113.

Hodder, I. \& P. Shand, 1988. The Haddenham long barrow: an interim statement. Antiquity 62, 349-53.

Kinnes, I., 1975. Monumental function in British Neolithic burial practices. World Archaeology 7, 16-29.

Kinnes, I., 1992. Non-megalithic Long Barrows and Allied Structures in the British Neolithic. London: British Museum.

Law, I.A. \& R.E.M. Hedges, 1989. A semi-automated pretreatment system and the pretreatment of older and contaminated samples. Radiocarbon 31, 247-53.

Mant, A.K., 1987. Knowledge acquired from post-War exhumations, in Death, Decay and Reconstruction, eds. A. Boddington, A.N. Garland \& R.C. Janaway. Manchester: Manchester University Press, 65-80.

Mays, S., 1998. The Archaeology of Human Bones. London: Routledge.

Morgan, F. de M. \& P. Ashbee, 1958. The excavation of two long barrows in Wessex. Antiquity 32, 104-11.

Morgan, R., 2006. Tree ring results, in A Woodland Archaeology: Neolithic Sites at Haddenham, eds. C. Evans \& I. Hodder. (McDonald Institute Monographs.) Cambridge: McDonald Institute for Archaeological Research, 177-87.

Oswald, A., C. Dyer \& M. Barber, 2001. The Creation of Monu- 
ments: Neolithic Causewayed Enclosures in the British Isles. London: English Heritage.

Piggott, S., 1966. 'Unchambered' long barrows in Neolithic Britain. Palaeohistoria 12, 381-93.

Ray, K. \& J. Thomas, 2003. In the kinship of cows: the social centrality of cattle in the earlier Neolithic of southern Britain, in Food, Culture and Identity in the Neolithic and Early Bronze Age, ed. M. Parker Pearson. (British Archaeological Reports, International Series 1117.) Oxford: BAR, 37-44.

Reimer, P.J., M.G.L. Baillie, E. Bard, A. Bayliss, J.W. Beck, C.J.H. Bertrand, P.G. Blackwell, C.E. Buck, G.S. Burr, K.B. Cutler, P.E. Damon, R.L. Edwards, R.G. Fairbanks, M. Friedrich, T.P. Guilderson, A.G. Hogg, K.A. Hughen, B. Kromer, F.G. McCormac, S. Manning, C. Bronk Ramsey, R.W. Reimer, S. Remmele, J.R. Southon, M. Stuiver, S. Talamo, F.W. Taylor, J. van der Plicht \& C.E. Weyhenmeyer, 2004. IntCal04 Terrestrial Radiocarbon Age Calibration, 0-26 cal. kyr вр. Radiocarbon 46, 1029-58.

Rodriguez, W.C., 1997. Decomposition of buried and submerged bodies, in Forensic Taphonomy: the Postmortem Fate of Human Remains, eds. W.D. Haglund \& M.H. Sorg. Boca Raton (FL): CRC Press, 459-67.

Saville, A., 1990. Hazleton North: the Excavation of a Neolithic Long Cairn of the Cotswold-Severn Group. London: English Heritage.

Scarre, C., P. Arias, G. Burenhult, M. Fano, L. Oosterbeek, R. Schulting, A. Sheridan \& A.Whittle, 2003. Megalithic chronologies, in Stones and Bones: Formal Disposal of the Dead in Atlantic Europe during the Mesolithic-Neolithic Interface 6000-3000 BC, ed. G. Burenhult. (British Archaeological Reports, International Series 1201.) Oxford: BAR, 65-111.

Shanks, M. \& C. Tilley, 1982. Ideology, symbolic power and ritual communication: a reinterpretation of Neolithic mortuary practices, in Symbolic and Structural Archaeology, ed. I. Hodder. Cambridge: Cambridge University Press, $129-54$.

Simmons, T., 2002. Taphonomy of a karstic cave execution site at Hrgar, Bosnia-Herzegovina, in Advances in Forensic Taphonomy: Method, Theory and Archaeological Perspectives, eds. W.D. Haglund \& M.H. Sorg. Boca Raton (FL): CRC Press, 264-75.

Simpson, D.D.A., 1968. Timber mortuary houses and earthen long barrows. Antiquity 42, 142-4.

Smith, M.J. \& M.B. Brickley, 2004. Analysis and interpretation of flint toolmarks found on bones from West Tump long barrow, Gloucestershire. International Journal of Osteoarchaeology 14, 18-33.

Stuiver, M. \& H.A. Polach, 1977. Reporting of ${ }^{14} \mathrm{C}$ data. $R a-$ diocarbon 19, 355-63.

Stuiver, M. \& P.J. Reimer, 1986. A computer program for radiocarbon age calculation. Radiocarbon 28, 1022-30.

Stuiver, M. \& P.J. Reimer, 1993. Extended ${ }^{14} \mathrm{C}$ data base and revised CALIB $3.0^{14} \mathrm{C}$ age calibration program. Radiocarbon 35, 215-30.

Stuiver, M., P.J. Reimer, E. Bard, J.W. Beck, G.S. Burr, K.A. Hughen, B. Kromer, F.G. McCormack, J. van der Plicht $\&$ M. Spur, 1998. INTCAL98 radiocarbon age calibration, 24,000-0 cal вр. Radiocarbon 40, 1041-84.

Thomas, J., 1991. Rethinking the Neolithic. Cambridge: Cambridge University Press.

Thomas, J., 1999. Understanding the Neolithic. London: Routledge.

Ubelaker, D.H., 2002. Approaches to the study of commingling in human skeletal biology, in Advances in Forensic Taphonomy: Method, Theory and Archaeological Perspectives, eds. W.D. Haglund \& M.H. Sorg. Boca Raton (FL): CRC Press, 331-51.

van der Plicht, J., S. Wijma, A.T. Aerts, M.H. Pertuisot \& H.A. Meijer, 2000. Status report: the Groningen AMS facility. Nuclear Instruments and Methods in Physics Research B 172, 58-65.

Waldron, T., 1987. The relative survival of the human skeleton: implications for palaeopathology, in Death, Decay and Reconstruction: Approaches to Archaeology and Forensic Science, eds. A. Boddington, A.N. Garland \& R.C. Janaway. Manchester: Manchester University Press, 55-64.

Ward, G.K. \& S.R. Wilson, 1978. Procedures for comparing and combining radiocarbon age determinations: a critique. Archaeometry 20, 19-31.

White, T.D., 2000. Human Osteology. 2nd edition. London: Academic Press.

Whittle, A., 1991. Wayland's Smithy, Oxfordshire: excavations at the Neolithic tomb in 1962-63 by R.J.C. Atkinson and S. Piggott. Proceedings of the Prehistoric Society 57 (2), 61-101.

Whittle, A., 2003. The Archaeology of People: Dimensions of Neolithic Life. London: Routledge.

Whittle, A., A. Barclay, A. Bayliss, L. McFadyen, R. Schulting \& M. Wysocki, this issue. Building for the dead: events, processes and changing worldviews from the thirty-eighth to the thirty-fourth centuries cal. вс in southern Britain.

Whittle, A., A. Bayliss \& M. Wysocki, this issue. Once in a lifetime: the date of the Wayland's Smithy long barrow.

Wysocki, M., 1998. The mortuary assemblages, in 'Parc le Breos Cwm Long Cairn, Gower, West Glamorgan: date, contents and context', by A. Whittle \& M. Wysocki. Proceedings of the Prehistoric Society, 64, 147-65.

Wysocki, M. \& A. Whittle, 2000. Diversity, lifestyles and rites: new biological and archaeological evidence from British Earlier Neolithic mortuary assemblages. Antiquity 74, 591-601.

Wysocki, M. \& A. Whittle, in preparation. On the people of the long barrows: human skeletal remains from West Kennet, Wayland's Smithy and Fussell's Lodge. 